\title{
EFEITO DE DIFERENTES CARBOIDRATOS NA RAÇÃO PRÉ-INICIAL DE FRANGOS DE CORTE SOBRE O DESEMPENHO E A ALOMETRIA DOS ÓRGÃOS
}

JOSÉ OTÁVIO BERTI SORBARA

Dissertação apresentada à Escola Superior de Agricultura "Luiz de Queiroz", Universidade de São Paulo, para obtenção do título de Mestre em Agronomia, Área de Concentração: Ciência Animal e Pastagens

Piracicaba

Estado de São Paulo

Março de 2003 


\title{
EFEITO DE DIFERENTES CARBOIDRATOS NA RAÇÃO PRÉ- INICIAL DE FRANGOS DE CORTE SOBRE O DESEMPENHO E A ALOMETRIA DOS ÓRGÃOS
}

\author{
JOSÉ OTÁVIO BERTI SORBARA \\ Zootecnista
}

Orientador: Prof. Dr. JOSÉ FERNANDO MACHADO MENTEN

Dissertação apresentada à Escola Superior de Agricultura "Luiz de Queiroz", Universidade de São Paulo, para obtenção do título de Mestre em Agronomia, Área de Concentração: Ciência Animal e Pastagens

\author{
Piracicaba \\ Estado de São Paulo - Brasil \\ Março de 2003
}


Dados Internacionais de Catalogação na Publicação (CIP) DIVISÃO DE BIBLIOTECA E DOCUMENTAÇÃO - ESALQ/USP

\section{Sorbara, José 0 távio Berti}

Efeito de diferentes carboidratos na ração pré-inicial de frangos de corte sobre 0 desempenho e a alometria dos órgãos / J osé 0 távio Berti Sorbara. - - Piracicaba, 2003

$60 \mathrm{p}$.

Dissertação (mestrado) - - Escola Superior de A gricultura Luiz de Q ueiroz, 2003. Bibliografia.

1. Carboidrato 2. Desempenho animal 3. Dieta animal 4. Frango de corte 5. N utrição animal I. Título

CDD 636.513

"Permitida a cópia total ou parcial deste documento, desde que citada a fonte - $O$ autor" 


\section{PARA:}

Meus pais Antonio e Cecília, que sempre me deram amor e carinho;

Meus irmãos Junior e Giuliana e minha segunda mãe Bernadete, que sempre foram amigos leais

COM MUITO AMOR, DEDICO.

A

Eliana que, com muita paciência, tem me ensinado a viver melhor

COM MUITO CARINHO, OFEREÇO. 


\section{AGRADECIMENTOS}

A Deus que me deu saúde e alegria para viver e o dom do discernimento para distinguir o certo do errado.

Ao meu orientador Prof. Dr. José Fernando M. Menten, um exemplo de profissional, por ter confiado em minha capacidade.

À Escola Superior de Agricultura "Luiz de Queiroz" e ao Conselho do Curso de Pós-graduação em Ciência Animal e Pastagens juntamente com a CAPES, que me deram oportunidade de aperfeiçoar meus conhecimentos.

Ao Prof. Dr. Valdomiro Shigeru Miyada que me ensinou muito mais conhecimentos além de nutrição.

Ao amigo Flávio Alves Longo, que cedeu parte de seu material de pesquisa e compartilhou seus conhecimentos. E que nossa amizade seja longa.

A Dra. Claudia Paz e ao doutorando Cláudio Melo, pelo auxílio e sugestões nas análises estatísticas.

Aos Professores da ESALQ, por todo ensinamento compartilhado.

Às secretárias do Departamento de Zootecnia da ESALQ, Vera e Cláudia, pela alegria que sempre transmitiram e aos funcionários Henrique, Antônio Carlos, Alexandre, Augusto, Ednézio, Paulo, Leonilço, Luiz Fernando, Airton, Pires, Adão, Benedito e todos os outros que sempre me ajudaram.

Aos amigos Adriana N. Figueiredo, Adriana Pedroso, Aline, Carlos Eduardo, Cláudia, Cláudio, Itibere, Juliana, Juliano, Liliana, Sara e Rodrigo.

E para todos que, de uma forma ou outra, me auxiliaram e me deram forças para realização do mestrado e que não foram nominalmente aqui citados. 


\section{SUMÁRIO}

Página

LISTA DE FIGURAS ................................................................................... vii

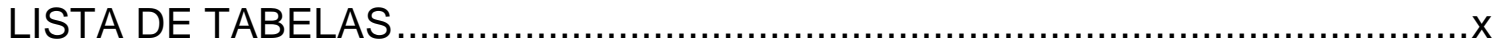

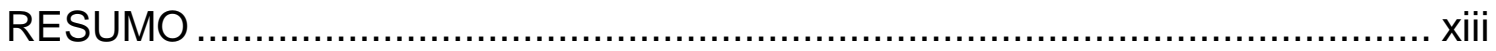

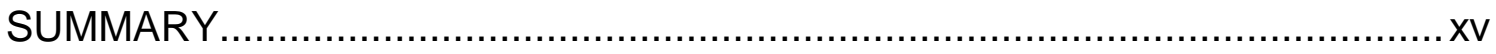

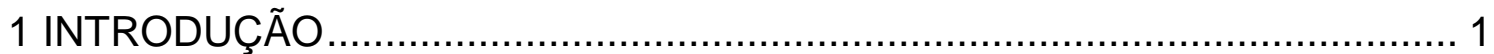

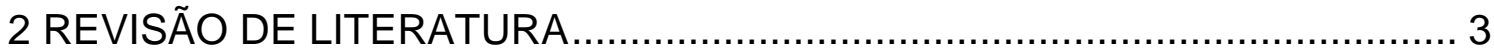

2.1 Desenvolvimento do sistema digestório ................................................... 3

2.2 Digestão e absorção de nutrientes ................................................................ 4

2.3 Importância da nutrição no período neonatal............................................ 5

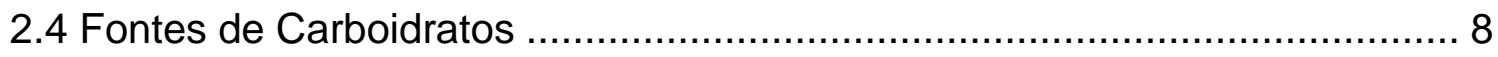

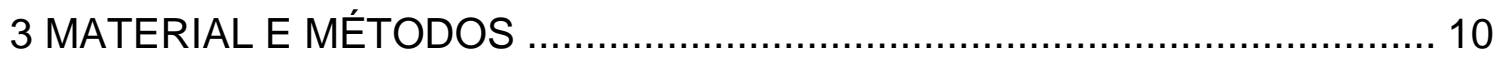

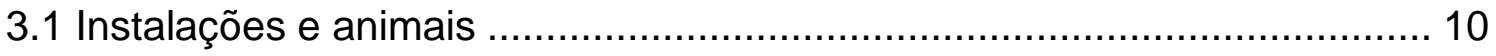

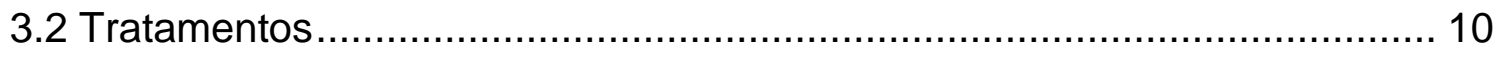

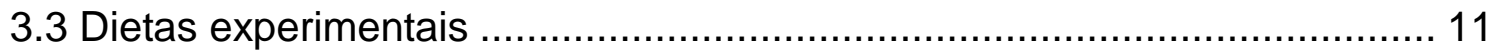

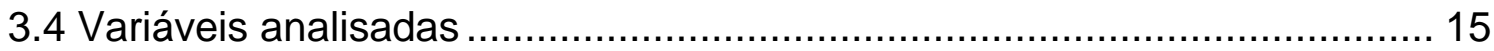

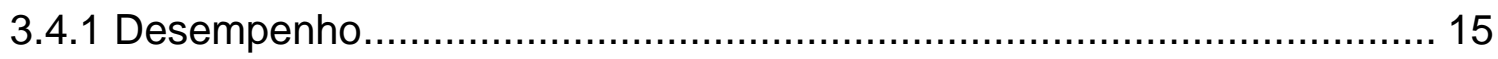

3.4.2 Alometria dos órgãos do sistema digestório e do saco vitelino ................ 15

3.5 Análise estatística ............................................................................. 16

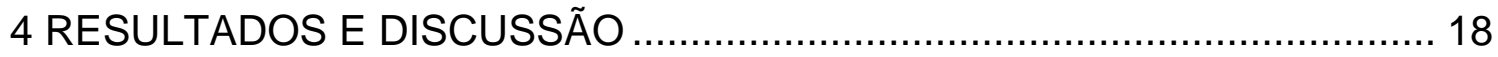

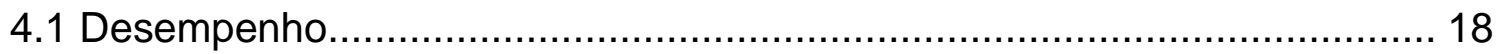

4.2 Alometria dos órgãos do sistema digestório e do saco vitelino.................... 21

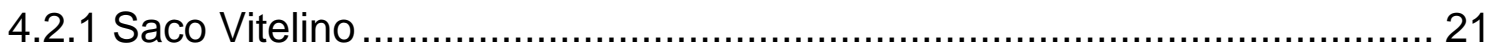

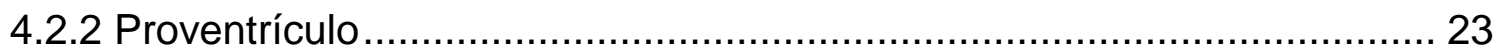

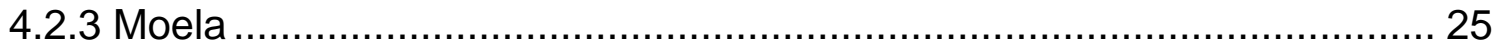

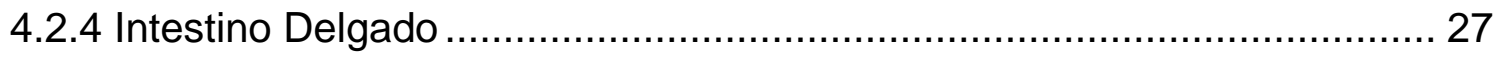




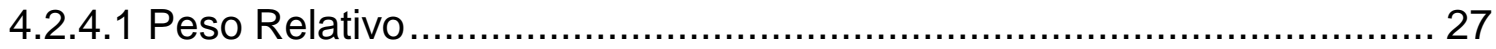

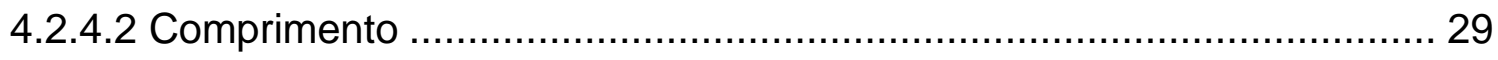

4.2.4.3 Relação Peso:Comprimento ......................................................... 31

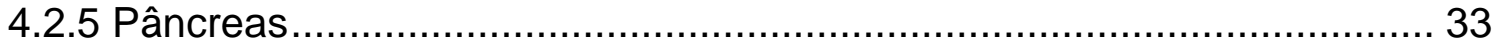

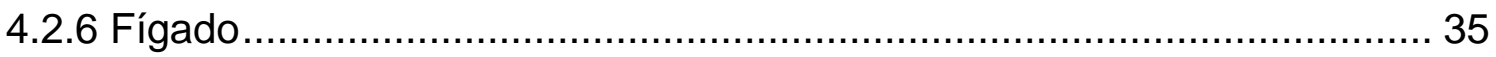

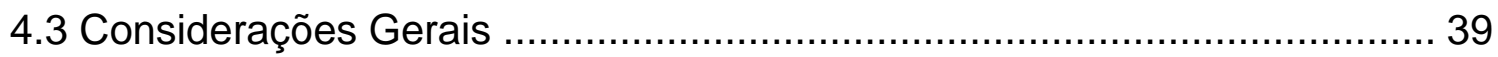

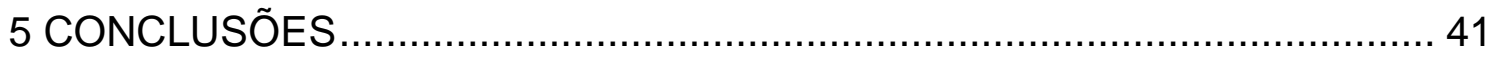

REFERÊNCIAS BIBLIOGRÁFICAS....................................................... 42

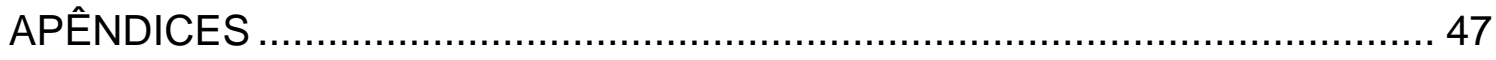




\section{LISTA DE FIGURAS}

Página

1 Peso relativo do saco vitelino (\% do peso vivo) de 1 a 7 dias de idade para cada tratamento e a equação geral de regressão do peso relativo do saco vitelino (SV) em função da idade $(x)(P<0,0001)$

22

2 Peso relativo do proventrículo (\% do peso vivo) de 1 a 7 dias de idade para cada tratamento e a equação geral de regressão do peso relativo do proventrículo (PROV) em função da idade $(x)(P<0,0001)$.

3 Peso relativo da moela (\% do peso vivo) de 1 a 7 dias de idade para cada tratamento e a equação geral de regressão do peso relativo da moela (MOE) em função da idade $(x)(P<0,0001)$.

4 Peso relativo do intestino delgado (ID) (\% do peso vivo) de 1 a 7 dias de idade para cada tratamento e a equação geral de regressão do peso relativo do ID (PID) em função da idade $(x)(P<0,0001)$.

5 Comprimento do intestino delgado de 1 a 7 dias de idade para cada tratamento e a equação geral de regressão do comprimento do intestino delgado (CID) em função da idade $(x)(P<0,0001)$.

6 Relação do peso do intestino delgado pelo comprimento do mesmo $(\mathrm{g} / \mathrm{cm})$ de 1 a 7 dias de idade para cada tratamento e a equação geral de regressão dessa relação (RPCID) em função da idade $(x)(P<0,0001)$ 
7 Peso relativo do pâncreas (\% do peso vivo) de 1 a 7 dias de idade para cada tratamento e a equação geral de regressão do peso relativo do pâncreas (PAN) em função da idade $(x)(P<0,0001)$. 34

8 Peso relativo do fígado (\% do peso vivo) de 1 a 7 dias de idade para cada tratamento e a equação geral de regressão do peso relativo do fígado (FIG) em função da idade $(x)(P<0,0001)$. 


\section{LISTA DE TABELAS}

Página

1 Valores de matéria seca (MS), energia bruta (EB), nitrogênio $(N)$, proteína bruta $(\mathrm{PB})$ e energia metabolizável aparente e corrigida para nitrogênio (EMAn).

2 Composição percentual e calculada das dietas experimentais fornecidas às aves na fase de 1 a 7 dias de idade (pré-inicial).

3 Composição percentual e calculada das dietas fornecidas às aves na fase de 7 a 21 (inicial) e de 21 a 42 dias (crescimento).

4 Valores médios do desempenho de frangos de corte de 1 a 7,7 a 21 e 21 a 42 dias de idade, valores de F, coeficiente de variação (CV) e comparação de médias por contrastes.

5 Valores médios do peso relativo do saco vitelino (\% do peso vivo) de 1 a 7 dias de idade, valores de $F$, coeficiente de variação (CV) e comparação de médias por contrastes.

6 Valores médios do peso relativo do proventrículo (\% do peso vivo) de 1 a 7, 21 e 42 dias de idade, valores de $F$, coeficiente de variação (CV) e comparação de médias por contrastes. 
7 Valores médios do peso relativo da moela (\% do peso vivo) de 1 a 7,21 e 42 dias de idade, valores de $F$, coeficiente de variação (CV) e comparação de médias por contrastes.

8 Valores médios do peso relativo do intestino (\% do peso vivo) de 1 a 7 , 21 e 42 dias de idade, valores de F, coeficiente de variação (CV) e comparação de médias por contrastes.

9 Valores médios do comprimento do intestino delgado $(\mathrm{cm})$ de 1 a 7, 21 e 42 dias de idade, valores de $F$, coeficiente de variação $(C V)$ e comparação de médias por contrastes.

10 Valores médios da relação do peso do Intestino Delgado (ID) pelo comprimento do mesmo $(\mathrm{g} / \mathrm{cm})$ de 1 a 7,21 e 42 dias de idade, valores de $F$, coeficiente de variação (CV) e comparação de médias por contrastes.

11 Valores médios do peso relativo do pâncreas (\% do peso vivo) de 1 a 7 , 21 e 42 dias de idade, valores de $F$, coeficiente de variação (CV) e comparação de médias por contrastes.

12 Valores médios do peso relativo do fígado (\% do peso vivo) de 1 a 7, 21 e 42 dias de idade, valores de $F$, coeficiente de variação (CV) e comparação de médias por contrastes.

A1 Consumo de ração (g) de 1 a 7,7 a 21 e 21 a 42 dias de idade de frangos de corte.

A2 Ganho de peso (g) de 1 a 7,7 a 21 e 21 a 42 dias de idade de frangos de corte

A3 Conversão alimentar de 1 a 7,7 a 21 e 21 a 42 dias de idade de frangos de corte. 
A5 Viabilidade criatória (\%) de 1 a 7,7 a 21 e 21 a 42 dias de idade

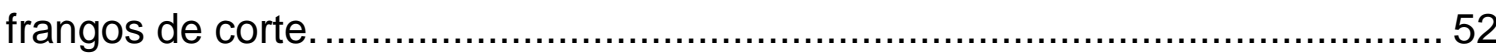

A6 Média de duas aves por parcela do peso relativo do saco vitelino (\% do peso vivo) de 1 a 7 dias de idade.

A7 Média de duas aves por parcela do peso relativo do proventrículo (\% do peso vivo) de 1 a 7,21 e 42 dias de idade.

A8 Média de duas aves por parcela do peso relativo da moela (\% do peso vivo) de 1 a 7,21 e 42 dias de idade.

A9 Média de duas aves por parcela do peso relativo do intestino delgado (\% do peso vivo) de 1 a 7,21 e 42 dias de idade.

A10 Média de duas aves por parcela do comprimento do intestino delgado de 1 a 7,21 e 42 dias de idade.

A11 Média de duas aves por parcela da relação do peso do intestino delgado pelo comprimento do mesmo de 1 a 7, 21 e 42 dias de idade.

A12 Média de duas aves por parcela do peso relativo do pâncreas (\% do peso vivo) de 1 a 7,21 e 42 dias de idade. 59

A13 Média de duas aves por parcela do peso relativo do fígado (\% do peso vivo) de 1 a 7,21 e 42 dias de idade. 


\title{
EFEITO DE DIFERENTES CARBOIDRATOS NA RAÇÃO PRÉ-INICIAL DE FRANGOS DE CORTE SOBRE O DESEMPENHO E A ALOMETRIA DOS ÓRGÃOS
}

\author{
Autor: JOSÉ OTÁVIO BERTI SORBARA \\ Orientador: Prof. Dr. JOSÉ FERNANDO MACHADO MENTEN
}

\section{RESUMO}

O estudo da nutrição na fase pré-inicial de frangos de corte é uma área de importância na busca da máxima expressão do potencial de crescimento. 0 presente trabalho teve por objetivo analisar os efeitos da alteração na qualidade da dieta pré-inicial, pela utilização de diferentes fontes de carboidratos, sobre o desenvolvimento de órgãos do sistema digestório e o desempenho das aves até os 42 dias de idade. $O$ experimento foi conduzido em baterias metálicas com aquecimento automático tendo seis tratamentos (rações contendo $20 \%$ de EM fornecida pelos carboidratos glicose, sacarose, amido de milho, amido de mandioca ou $5 \%$ de lactose de um a sete dias de idade) com quatro repetições de 26 aves. Avaliou-se o desempenho das aves de 1 a 7, 7 a 21 e 21 a 42 dias. Para avaliação alométrica dos órgãos do sistema digestório foram feitos abates do primeiro ao sétimo, ao $21^{\circ}$ e ao $42^{\circ}$ dia de idade das aves. Observou-se um efeito de tratamento no consumo de ração $(P=0,0062)$ e no peso vivo $(P=0,0975)$ de um a sete dias de idade, e na conversão alimentar $(P=0,0163)$ na fase de 21 a 42 dias de idade. A viabilidade criatória não foi afetada 
significativamente por nenhum dos tratamentos em nenhuma das fases assim como o consumo de ração de sete a 21 e de 21 a 42 dias de idade. Aos 21 e 42 dias de idade não houve diferença estatística entre os tratamentos para o peso vivo. A conversão alimentar de um a sete e de sete a 21 dias de idade também não foi afetada pelos tratamentos. Não foi observado efeito significativo de tratamento em nenhuma das fases de criação para o peso relativo do saco vitelino, do proventrículo e para relação peso:comprimento do intestino delgado. $\mathrm{Na}$ fase de um a sete dias de idade observou-se efeito significativo de tratamento para o peso relativo da moela e do intestino delgado e para o comprimento absoluto do intestino delgado. Aos 21 dias de idade não se observou efeito significativo de tratamento para nenhuma variável. Aos 42 dias de idade observou-se efeito de tratamento sobre o peso relativo do pâncreas e do intestino delgado. Conclui-se que o uso dos carboidratos: glicose, sacarose, amido de milho e amido de mandioca foi benéfico para o desempenho das aves na fase de um a sete dias de idade. O melhor desempenho das aves nesses tratamentos, possivelmente, ocorreu devido à melhora da capacidade do sistema digestório, especialmente do peso relativo do intestino delgado. Entretanto, o efeito observado até os sete dias de idade das aves não foi mantido nas fases posteriores. 


\title{
EFFECTS OF DIFFERENT CARBOHYDRATES IN THE PRE-INITIAL BROILER CHICKEN FEED ON THE PERFORMANCE AND ON THE ORGANS ALLOMETRIC GROWTH
}

\author{
Author: JOSÉ OTÁVIO BERTI SORBARA \\ Adviser: Prof. Dr. JOSÉ FERNANDO MACHADO MENTEN
}

\section{SUMMARY}

The study of the broiler chicken pre-initial nutrition is an important field to maximize the growth potential expression. The present work analyzed the effect of the quality alteration in the pre-initial feed by carbohydrates sources on the gastrointestinal tract development and on the performance through 42 days. The trial was carried out in brooder batteries with six treatments (feed with $20 \% \mathrm{ME}$ requirement from glucose, sucrose, corn starch, cassava starch or $5 \%$ of lactose, the birds received this feed only in the first week of age) and four replications with 26 chicks. The performance was analyzed from 1 to 7,7 to 21 and from 21 to 42 days. Chickens were killed to analyze the allometric growth of the gastrointestinal organs from the first to seventh day and on the $21^{\text {st }}$ and $42^{\text {nd }}$ day. The feed consumption ( $P=0,0062)$, body weight $(P=0,0975)$ in the first week and feed conversion from $21^{\text {st }}$ to $42^{\text {nd }}(P=0,0163)$ were affected by the treatments. The livability was not affected by any treatment in any period. The feed consumption from 7 to 21 and from 21 to 42 days was not affected. Also the body weight at 21 and 42 days was not affected by the treatments. The feed 
conversion from 1 to 7 and from 7 to 21 days was not affected by the treatments. The yolk sack, proventriculus, and the small intestine density were not affected by the treatments. From the first to the seventh day the treatments affected the gizzard weight and the small intestine weight and length. The treatments did not affect any variable at 21 days. At 42 days the pancreas and the small intestine weight were affected by the treatments. In conclusion the carbohydrates: glucose, sucrose, corn starch and cassava starch were beneficial for the performance from 1 to 7 days of age. These treatments resulted in better performance probably due to improvement in the gastrointestinal tract and absorbability capacity, specially the allometric weight of small intestine. However, at 21 and 42 days of age the improvement on performance was not detected. 


\section{INTRODUÇÃO}

São vários os trabalhos que estudam o efeito da restrição de alimento nas primeiras horas de vida da ave sobre o desempenho e o desenvolvimento de órgãos. Os estudos da restrição nas primeiras horas são valiosos e em sua maioria concluem que quanto mais cedo se fornece o alimento melhor é o desempenho da ave. No entanto, é difícil diminuir o tempo entre a eclosão do pintinho no nascedouro até o momento da chegada nas instalações onde serão criados. Outra opção é trabalhar com ingredientes de melhor qualidade em dietas complexas, a exemplo do que já ocorre em suínos, tentando dessa forma, melhorar a capacidade de digestão e absorção dos nutrientes pelo animal, minimizando os efeitos do período de restrição que sofreu entre a eclosão e a chegada onde será criado.

A nutrição na fase neonatal de frangos de corte é uma área de importância na busca da máxima expressão do potencial de crescimento e produção de carne. A taxa de crescimento de frangos tem aumentado substancialmente nas ultimas décadas, fazendo com que o peso especificado para o abate seja atingido cada vez mais precocemente, elevando assim, a representatividade da fase pós-eclosão. Penz Jr. \& Vieira (2000) afirmaram que perdas no desenvolvimento inicial de frangos de corte são mais limitantes hoje em dia do que foram no passado.

O saco vitelino da ave, logo após a eclosão, é rico em lipídeos, mas muito pobre em carboidratos. Esta reserva não supre totalmente a energia necessária para a ave pós-eclosão. Com isso, verifica-se uma necessidade de gliconeogênese a partir da proteína do saco vitelino e corporal, já que os 
lipídeos não contribuem no metabolismo de síntese de glicose.

As reservas provenientes do saco vitelino das aves se esgotam em poucos dias após a eclosão (Noy et al., 1996). O saco vitelino desempenha um papel como fonte de energia temporária até o momento em que a ave apresenta capacidade de obter sua energia a partir do alimento oferecido. Assim, com o objetivo de dar suporte ao seu crescimento, as aves necessitam adquirir rápida capacidade de absorver nutrientes externos (Jin et al., 1998). Noy \& Sklan (1997) comentaram que a entrada de nutrientes do saco vitelino e da dieta exógena no intestino delgado servem como um estímulo ao crescimento e desenvolvimento do sistema digestório e, conseqüentemente, das funções de digestão e absorção.

Em função das evidências da importância da alimentação neonatal, o presente trabalho teve por objetivo verificar os efeitos da alteração na qualidade da dieta pré-inicial, promovida pela utilização de diferentes fontes de carboidratos, sobre o desenvolvimento de órgãos do sistema digestório e o desempenho das aves até os 42 dias de idade. 


\section{REVISÃO DE LITERATURA}

\subsection{Desenvolvimento do sistema digestório}

As taxas de crescimento e a eficiência alimentar em aves dependem basicamente da disponibilidade de nutrientes e de oxigênio para os tecidos. Dibner (1996) propôs que a taxa de crescimento inicial da ave pode ser afetada pela quantidade de saco vitelino residual, qualidade e quantidade de alimento e água, nível de enzimas pancreáticas e intestinais, área de superfície do trato digestório, transportadores de nutrientes e, sobretudo, pela digestibilidade dos nutrientes.

Para que os frangos de corte possam expressar ao máximo seu potencial de crescimento, eles precisam adaptar-se rapidamente à nutrição exógena. $\mathrm{Na}$ fase embrionária dependem basicamente dos lipídeos como fonte de energia. Logo após a eclosão, quando os nutrientes passam a ser absorvidos no intestino, a principal fonte de energia são os carboidratos (Dibner, 1996).

O comprimento do intestino delgado aumenta durante a primeira semana mesmo quando a ave não recebe alimento. Contudo, para o desenvolvimento das vilosidades, a alimentação é essencial (Baranyiová \& Holman, 1976). O atraso no estímulo com alimento causa comprometimento das vilosidades, até a sexta semana de idade das aves sendo que a profundidade das criptas e o número de enterócitos por secção longitudinal das vilosidades aumentam e a densidade dos enterócitos nos diferentes segmentos do intestino não variam, mas a concentração das vilosidades (vilos $/ \mathrm{cm}^{2}$ ) decresce com a idade (Michael \& Hodges, 1973; Jin et al., 1998). 
O rápido crescimento do intestino atinge um pico entre três e sete dias e declina em seguida (Murakami et al., 1992). Durante a primeira semana de vida dos pintos de corte, o pâncreas e o intestino delgado aumentam quatro vezes e o fígado duas vezes mais do que o peso do corpo sendo que o peso do pâncreas pode representar mudanças na capacidade digestiva da ave, devido à alta correlação entre o peso do mesmo com a atividade das enzimas digestivas pancreáticas (Nitsan et al. 1995; Corless \& Sell, 1999).

\subsection{Digestão e absorção de nutrientes}

Noy \& Sklan (1995) relataram que o aproveitamento de um nutriente pela ave está na dependência da digestão e absorção deste a partir do trato digestório, e que a digestão de macromoléculas requer suficiente hidrólise enzimática para ser absorvida. Em aves recém-nascidas, quando ocorre um rápido aumento na taxa de consumo alimentar, um maior tempo de retenção pode ser necessário para a hidrólise no intestino delgado, promovendo maior exposição do alimento à atividade enzimática. Vieira \& Moran Jr. (1999a) comentaram que, geralmente, o trato digestório das aves não é totalmente competente para a digestão e absorção até duas semanas de idade.

As enzimas digestivas do pâncreas iniciam a digestão, mas uma completa digestão de certos carboidratos e peptídeos dependem da atividade de enzimas localizadas na superfície da mucosa intestinal (Tarvid, 1995). As dissacaridases são enzimas ligadas a membrana intestinal, e qualquer alteração na superfície da membrana pode alterar a sua atividade.

A concentração de carboidrato da dieta promove mudanças na atividade das dissacaridases. Siddons (1972) observou que dietas sem carboidratos levaram a redução da atividade das dissacaridases e Sell et al. (1989) encontraram que, alimentando aves com dietas ricas em carboidratos, as atividades das dissacaridases aumentavam, comprovando que o carboidrato presente na dieta estimula a atividade das dissacaridases intestinais. 
Jin et al. (1998) concluíram que a imaturidade do sistema digestório de aves na fase pré-inicial reduz a capacidade de utilização dos nutrientes. Comentaram, ainda, que tendo-se em mãos informações sobre os processos digestivos e absortivos das aves, pode-se determinar e incrementar estratégias nutricionais para melhorar a utilização de nutrientes em aves jovens.

A deficiência no aproveitamento dos nutrientes pelas aves parece levar a um decréscimo dos valores de energia metabolizável das dietas. Resultados mostraram que esses valores são menores principalmente entre quatro e sete dias de idade dos pintinhos (Murakami et al., 1992; Sulistyanto et al., 1999). Concordando, Corless \& Sell (1999) relataram que valores de energia metabolizável de dietas aos quatro, sete e 14 dias de idade, determinados com perus, foram inferiores aos calculados com base nos valores energéticos dos ingredientes encontrados na tabela do NRC (1994).

Menten et al. (2002) e Longo et al. (2002) determinaram os valores de energia metabolizável aparente corrigida para nitrogênio (EMAn) para o milho, farelo de soja e glicose em frangos de corte com idade entre quatro e sete dias e os valores de EMAn para o milho e farelo de soja foram menores do que os encontrados em tabelas mas o valor de EMAn da glicose foi semelhante ao encontrado na literatura para outras idades de frangos de corte, mostrando dessa forma que alimentos de estrutura mais simples são melhor absorvidos que alimentos de estrutura complexa como é o caso do milho e o farelo de soja.

\subsection{Importância da nutrição no período neonatal}

Dibner \& Pierson (1997) relataram que um atraso no início do consumo de ração e de água pode ter conseqüências a longo prazo no desempenho subseqüente da ave.

Dietas com $60 \%$ de milho elevaram o conteúdo de glicogênio hepático de perus, de níveis abaixo de $10 \mathrm{mg} / \mathrm{g}$ para níveis superiores a $100 \mathrm{mg} / \mathrm{g}$, entre o nascimento e dois dias de idade (Turner,1999). Do ponto de vista prático, o 
milho pode ser uma boa fonte de carboidrato sendo que o uso de dietas com elevado teor de proteína e carboidratos de baixa disponibilidade pode fazer com que as necessidades iniciais de glicose sejam atendidas pelo processo de gliconeogênese (Lilburn, 1998).

Pós-eclosão, o acesso precoce à glicose pode ser possível por aplicação via oral de açúcares (Waldroup et al., 1974), mas se a glicose aplicada for em concentrações excessivas pode levar a um processo de diarréia (Moran Jr., 1988). Moran Jr. (1990), alimentando aves neonatas, observou que uma dieta contendo $20 \%$ de glicose promoveu um aumento de ganho de peso e consumo alimentar.

Ressaltando a importância de uma dieta que atenda às exigências nutricionais, além da suplementação com fontes de carboidratos, Vieira \& Moran Jr. (1999b), alimentando aves somente com milho nos primeiros três dias, observaram, além de redução na mortalidade, queda no ganho de peso das aves nesse intervalo de tempo, a qual persistiu mesmo após o acesso a uma dieta basal até 49 dias de idade. Um menor rendimento de carcaça e maior acúmulo de gordura abdominal também foram observados para essas aves, sugerindo que um desbalanço nutricional, principalmente devido à deficiência em proteína nessa fase, prejudicaria o desenvolvimento normal das aves.

Moran Jr. (1990) e Chamblee et al. (1992), estudando a nutrição de frangos e perus jovens, encontraram que o início do crescimento das aves, acompanhado da absorção das reservas vitelínicas e ingestão de carboidratos, foi essencial para se atingir o máximo potencial de crescimento. Aves com deficiências nutricionais na fase pré-inicial dificilmente atingem o mesmo peso que aves sem deficiências (Nir \& Levanon, 1993). Akiba \& Murakami (1995) descreveram que a manipulação da nutrição precoce de frangos de corte pode modificar seu crescimento e acúmulo de gordura.

Em algumas espécies o excesso de consumo de alimento no início da vida favorece a maturação e o aumento no número de adipócitos; entretanto, 
com frangos de corte estas evidências não foram confirmadas (Penz Jr. \& Vieira, 2000).

O uso de rações na primeira semana de idade das aves sem a adição de gordura reduz a deposição de gordura abdominal aos 49 dias de idade e níveis elevados de proteína na dieta inicial ( 0 a 14 dias) pode prejudicar 0 desenvolvimento das aves neste período, mas é benéfico no sentido de maximizar o ganho de peso e a eficiência alimentar, durante a fase final (28 a 49 dias) (Hargis \& Creger, 1980).

A proporção de músculo de peito ao abate é cerca de 4 a 10\% maior em aves com rápido acesso à alimentação, demonstrando a importância que a alimentação neonatal tem nas características finais da carcaça (Noy \& Sklan, 1998).

Levando em consideração que aves recém eclodidas possuem todas as células responsáveis pelo crescimento muscular ativas, uma disponibilidade adequada de proteína nessa fase pode ser particularmente importante para a taxa de crescimento sendo que dietas ricas em carboidratos podem beneficiar o desenvolvimento da ave neonata através do aumento da glicose circulante e economia da proteína corporal (Vieira \& Moran Jr., 1999b).

Penz Jr. \& Vieira (1998) comentaram que a dieta pré-inicial poderá ser produzida com os melhores ingredientes disponíveis na fábrica de ração, pois a quantidade consumida nesta fase corresponde a aproximadamente $3,5 \%$ do total da dieta que será consumida pelos frangos de corte até o abate. Lilburn (1998) propôs que combinações de ingredientes de alta digestibilidade e elevado teor protéico podem ser usados para atender tanto as exigências energéticas como protéicas para aves jovens. $O$ autor recomendou que esta dieta seja utilizada nos primeiros sete ou dez dias de vida das aves, e que deve ser considerada como um investimento e não um custo no sistema de produção. 


\subsection{Fontes de Carboidratos}

Os carboidratos são cadeias carbônicas hidratadas $\left(\mathrm{CH}_{2} \mathrm{O}\right)_{n}$, onde $n$ é maior ou igual a três. Os carboidratos são divididos em monossacarídeos, oligossacarídeos e polissacarídeos sendo os monossacarídeos a unidade básica dos carboidratos e a fonte de maior parte da energia utilizada pelo organismo animal (Vieira, 2002).

Existem quatro monossacarídeos de importância: glicose, frutose, galactose e manose. A glicose é o monossacarídeo de maior importância na nutrição e no metabolismo das aves visto que é o açúcar da circulação sanguínea. A D-glicose é produzida comercialmente pela hidrolise ácida do amido de milho com o nome de dextrose (Vieira, 2002).

Os oligossacarídeos contêm de dois a 10 monossacarídeos conectados por meio de ligações glicosídicas que ocorrem entre o carbono 1 de uma molécula e o grupo hidroxila ligado ao carbono do outro monossacarídeo. Os oligossacarídeos de importância para os animais são: sacarose, lactose, maltose e isomaltose. A sacarose é um dissacarídeo formado pelos monossacarídeos glicose e frutose ligados entre si por uma ligação glicosídica entre os carbonos 1 da glicose e o carbono 2 da frutose. A sacarose é normalmente encontrada com o nome comercial de sacarose de cana ou açúcar cristal e refinado. A lactose é um dissacarídeo, proveniente principalmente do leite, formado por uma glicose e uma galactose ligados através de uma ponte $\beta$-glicosídica estabelecidas entre os carbonos 1 e 4 dos dois monossacarídeos (Rostagno, 1994).

Os polissacarídeos são compostos com 10 ou mais monossacarídeos. $O$ amido é o carboidrato de reserva das plantas sendo formado por dois polissacarídeos estruturalmente diferentes. Um dos componentes, chamado amilose, é uma molécula linear composta por aproximadamente 100 unidades de D-glicopiranose ligadas uniformemente por pontes glicosídicas $\alpha-1,4$, que conferem forma helicoidal à molécula. $O$ segundo componente, a amilopectina, 
é constituído por mil unidades de glicose ou mais, também unidas por ligações $\alpha-1,4$. No entanto, há pontos de ramificação, onde existem ligações $\alpha-1,6$. Esse tipo de ponte constitui cerca de $4 \%$ das ligações totais, ou seja, uma a cada vinte e cinco unidades de glicose, aproximadamente, no amido. Quando o amido é tratado com água quente ele se separa em duas frações. A fração mais solúvel é composta por amilose enquanto a parte insolúvel é composta por amilopectina (Vieira, 2002).

Normalmente, os ingredientes para rações são compostos por 10 a $20 \%$ de amilopectina e de 80 a $90 \%$ de amilose do total de amido. $O$ amido de milho é formado por aproximadamente $70 \%$ de amilose e $30 \%$ de amilopectina e o amido de mandioca em geral tem a composição inversa, sendo $30 \%$ de amilose e $70 \%$ de amilopectina. No entanto, as relações de amilose e amilopectina não são fixas e podem variar de acordo com a genética da planta e com o tamanho do grânulo (Moran Jr., 1982). 


\section{MATERIAL E MÉTODOS}

O experimento foi desenvolvido na Escola Superior de Agricultura "Luiz de Queiroz" da Universidade de São Paulo, em Piracicaba, SP.

Foram utilizados cinco ingredientes: glicose, sacarose, amido de milho, amido de mandioca e lactose a fim de promover alterações na qualidade do carboidrato fornecido pela dieta na fase pré-inicial.

\subsection{Instalações e animais}

O experimento foi conduzido em sala climatizada no Laboratório de Nutrição e Crescimento Animal do Departamento de Zootecnia.

Foram utilizados 624 pintos de corte machos de 1 dia de idade da marca comercial AGROSS, provenientes de matrizes com 62 semanas de idade, alojados em baterias metálicas com aquecimento automático, distribuídos em delineamento inteiramente casualizado com seis tratamentos e quatro repetições de 26 aves cada.

\subsection{Tratamentos}

Os tratamentos foram aplicados de 1 a 7 dias, sendo que no período subseqüente ( 8 a 42 dias), as aves tiveram acesso a uma dieta basal padrão.

1 - dieta milho e farelo de soja (testemunha); 2 - dieta milho e farelo de soja + glicose; 3 - dieta milho e farelo de soja + sacarose, 4 - dieta milho e farelo de soja + amido de milho; 5 - dieta milho e farelo de soja + amido de 
mandioca; 6 - dieta milho e farelo de soja + lactose.

\subsection{Dietas experimentais}

As composições dos ingredientes utilizados para formular as rações experimentais são apresentados na Tabela 1, enquanto as dietas experimentais são apresentadas na Tabela 2.

As fontes de carboidratos, com exceção da lactose, foram incluídas em substituição a $20 \%$ da energia metabolizável aparente corrigida para nitrogênio (EMAn) da ração basal com base nos dados fornecidos por Menten et al. (2002) e Longo et al. (2002). A lactose foi adicionada à dieta em $5 \%$ devido ao seu baixo valor de EMAn e procurando com isso evitar problemas de inclusão em excesso que poderiam provocar problemas de diarréia.

$\mathrm{Na}$ Tabela 3 são apresentadas as composições das dietas a base de milho e farelo de soja fornecidas nos períodos subseqüentes (8 a 42 dias) de criação das aves.

Todas as dietas foram formuladas para atender ou exceder as exigências das aves segundo Rostagno et al. (2000). Somente o valor de EM calculado apresentado na Tabela $2(2800 \mathrm{kcal} / \mathrm{kg})$ não corresponde ao valor sugerido pelos autores $(2950 \mathrm{kcal} / \mathrm{kg}$ ). Para formulação da dieta testemunha (milho e farelo de soja) utilizaram-se os valores de EMAn dos ingredientes preconizados na literatura; posteriormente a EMAn dos ingredientes foi ajustada para os valores específicos para fase pré-inicial segundo Menten et al. (2002) e Longo et al. (2002). Essa estratégia foi adotada visando evitar um desbalanço nutricional, uma vez que as exigências dos demais nutrientes preconizadas na literatura para aves nessa fase foram determinadas considerando valores de energia não corrigidos. 
Tabela 1. Valores de matéria seca (MS), energia bruta (EB), nitrogênio $(N)$, proteína bruta $(\mathrm{PB})$ e energia metabolizável aparente e corrigida para nitrogênio (EMAn).

\begin{tabular}{lccccc}
\hline \multicolumn{1}{c}{ Ingredientes } & $\begin{array}{c}\mathrm{MS} \\
(\%)\end{array}$ & $\begin{array}{c}\mathrm{EB}^{1} \\
(\mathrm{kcal} / \mathrm{g})\end{array}$ & $\begin{array}{c}\mathrm{EMAn}^{2} \\
(\mathrm{kcal} / \mathrm{g})\end{array}$ & $\begin{array}{c}\mathrm{N}^{1} \\
(\%)\end{array}$ & $\begin{array}{c}\mathrm{PB}^{1} \\
(\%)\end{array}$ \\
\hline Milho & 89,92 & 3,943 & 3,213 & 1,48 & 9,26 \\
Farelo de soja $_{\text {Glicose }^{\mathrm{a}}}$ & 91,67 & 4,197 & 2,085 & 7,60 & 47,52 \\
Sacarose $^{\mathrm{b}}$ & 93,17 & 3,819 & 3,427 & 0,16 & 1,03 \\
Amido de milho $^{\mathrm{c}}$ & 97,82 & 3,922 & 3,524 & 0,14 & 0,85 \\
Amido de mandioca $^{\mathrm{d}}$ & 89,30 & 3,619 & 3,269 & 0,23 & 1,43 \\
Lactose $^{\mathrm{e}}$ & 97,81 & 3,770 & 3,690 & 0,14 & 0,87 \\
\hline
\end{tabular}

${ }^{1}$ Valores expressos na matéria natural.

${ }^{2}$ Valor de energia metabolizável para fase pré-inicial segundo Longo et al. (2002) e Menten et a. (2002).

${ }^{\mathrm{a} X a r o p e}$ de glicose MOR-REX ${ }^{\circledR} 1940$ (Corn Products Brasil)

${ }^{\mathrm{b}}$ Açúcar de cana cristal (União ${ }^{\circledR}$ )

${ }^{\mathrm{C}} \mathrm{AMISOL}{ }^{\circledR} 3408$ (Corn Products Brasil)

${ }^{\mathrm{d}}$ Fécula de mandioca comercial

éactose M-30 (M. Cassab Comércio e Indústria Ltda.) 
Tabela 2. Composição percentual e calculada das dietas experimentais fornecidas às aves na fase de 1 a 7 dias de idade (pré-inicial).

\begin{tabular}{|c|c|c|c|c|c|c|}
\hline \multirow[b]{2}{*}{ Ingredientes (\%) } & \multicolumn{6}{|c|}{ Tratamentos } \\
\hline & Testem. & Glicose & Sacarose & $\begin{array}{l}\text { Amido } \\
\text { milho }\end{array}$ & $\begin{array}{c}\text { Amido } \\
\text { mandioca }\end{array}$ & Lactose \\
\hline Milho $^{1}$ & 61,19 & 41,03 & 41,79 & 39,58 & 43,27 & 52,38 \\
\hline Farelo de soja $^{1}$ & 33,57 & 37,35 & 37,27 & 37,48 & 36,97 & 35,28 \\
\hline Glicose $^{2}$ & - & 16,34 & - & - & - & - \\
\hline Sacarose $^{2}$ & - & - & 15,89 & - & - & - \\
\hline A. Milho ${ }^{2}$ & - & - & - & 17,13 & - & - \\
\hline A. Mandioca ${ }^{2}$ & - & - & - & - & 15,18 & - \\
\hline Lactose $^{3}$ & - & - & - & - & - & 5,00 \\
\hline Fosfato bicálcico & 1,86 & 1,90 & 1,90 & 1,90 & 1,89 & 1,87 \\
\hline Calcário calcítico & 1,04 & 0,97 & 1,00 & 0,99 & 1,00 & 1,02 \\
\hline Óleo vegetal & 1,29 & 1,43 & 1,17 & 1,93 & 0,70 & 3,43 \\
\hline Sal & 0,40 & 0,40 & 0,40 & 0,40 & 0,40 & 0,40 \\
\hline DL- Metionina & 0,18 & 0,19 & 0,19 & 0,19 & 0,19 & 0,18 \\
\hline L-lisina $\mathrm{HCl}$ & 0,22 & 0,14 & 0,14 & 0,14 & 0,15 & 0,19 \\
\hline Cl-Colina 60\% & 0,05 & 0,05 & 0,05 & 0,05 & 0,05 & 0,05 \\
\hline Supl. Vitamínico ${ }^{4}$ & 0,10 & 0,10 & 0,10 & 0,10 & 0,10 & 0,10 \\
\hline Supl. Mineral ${ }^{5}$ & 0,10 & 0,10 & 0,10 & 0,10 & 0,10 & 0,10 \\
\hline \multicolumn{7}{|c|}{ Composição calculada } \\
\hline EM (kcal/g) & 2800 & 2800 & 2800 & 2800 & 2800 & 2800 \\
\hline PB (\%) & 21,915 & 21,915 & 21,915 & 21,915 & 21,915 & 21,915 \\
\hline Metionina (\%) & 0,507 & 0,507 & 0,507 & 0,507 & 0,507 & 0,507 \\
\hline Met. + cis. (\%) & 0,874 & 0,862 & 0,863 & 0,860 & 0,863 & 0,869 \\
\hline Lisina (\%) & 1,307 & 1,307 & 1,307 & 1,307 & 1,307 & 1,307 \\
\hline Arginina (\%) & 1,393 & 1,442 & 1,442 & 1,440 & 1,437 & 1,416 \\
\hline Treonina (\%) & 0,833 & 0,838 & 0,839 & 0,835 & 0,838 & 0,836 \\
\hline Triptofano (\%) & 0,258 & 0,271 & 0,271 & 0,271 & 0,270 & 0,264 \\
\hline Fósforo disp. (\%) & 0,466 & 0,466 & 0,466 & 0,466 & 0,466 & 0,466 \\
\hline Cálcio (\%) & 0,988 & 0,988 & 0,988 & 0,988 & 0,988 & 0,988 \\
\hline
\end{tabular}

${ }^{1}$ Utilizou-se o valor de EMAn do ingrediente para essa fase (Menten et al., 2002).

${ }^{2}$ Utilizou-se o valor de EMAn do ingrediente para essa fase (Longo et al., 2002). O ingrediente contribuiu com $20 \%$ do valor EMAn da dieta testemunha.

${ }^{3}$ Utilizou-se dos valores de EMAn dos ingredientes para essa fase (Longo et al., 2002). O ingrediente teve uma inclusão de $5 \%$.

${ }^{4}$ Concentração por kg de produto: vit. A, 10.000 .000 UI; vit. $D_{3}, 2.000 .000 \mathrm{UI}$; vit. E, 12,5 g; vit. $K_{3}, 2,5$ g; vit. $B_{1}, 2,4$ g; vit. $B_{2}, 6,0$ g; vit. $B_{6}, 3,2$ g; vit. $B_{12}, 12$ g; ácido fólico, 1,0 g; pantotenato de Ca, 12,5 g; niacina, $30 \mathrm{~g}$; selênio, 0,2 g; BHT, $15 \mathrm{~g}$.

${ }^{5}$ Concentração por kg de produto: manganês, $65 \mathrm{~g}$; cobre, $12 \mathrm{~g}$; zinco, $50 \mathrm{~g}$; ferro, $40 \mathrm{~g}$; iodo, 1 g. 
Tabela 3. Composição percentual e calculada das dietas fornecidas às aves na fase de 7 a 21 (inicial) e de 21 a 42 dias (crescimento).

\begin{tabular}{|c|c|c|}
\hline Ingredientes (\%) & $\begin{array}{l}\text { Fase Inicial } \\
7 \text { a } 21 \text { dias }\end{array}$ & $\begin{array}{c}\text { Fase Crescimento } \\
21 \text { a } 42 \text { dias }\end{array}$ \\
\hline Milho & 62,60 & 67,81 \\
\hline Farelo de soja & 32,50 & 27,53 \\
\hline Fosfato bicálcico & 1,76 & 1,57 \\
\hline Calcário calcítico & 1,02 & 0,97 \\
\hline Óleo vegetal & 1,12 & 1,12 \\
\hline Sal & 0,40 & 0,40 \\
\hline DL- Metionina & 0,17 & 0,16 \\
\hline L-lisina $\mathrm{HCl}$ & 0,20 & 0,23 \\
\hline Cl-Colina 60\% & 0,05 & 0,05 \\
\hline Supl. Vitamínico ${ }^{1}$ & 0,08 & 0,06 \\
\hline Supl. Mineral $^{2}$ & 0,10 & 0,10 \\
\hline & Composição calculada & \\
\hline EM (kcal/g) & 3050 & 3100 \\
\hline PB (\%) & 21,220 & 19,300 \\
\hline Metionina (\%) & 0,491 & 0,453 \\
\hline Met. + cis. (\%) & 0,853 & 0,790 \\
\hline Lisina (\%) & 1,260 & 1,156 \\
\hline Arginina (\%) & 1,362 & 1,213 \\
\hline Treonina (\%) & 0,818 & 0,741 \\
\hline Triptofano (\%) & 0,252 & 0,222 \\
\hline Fósforo disp. (\%) & 0,448 & 0,406 \\
\hline Cálcio (\%) & 0,955 & 0,874 \\
\hline \multicolumn{3}{|c|}{$\begin{array}{l}\text { Concentração por } \mathrm{kg} \text { de produto: vit. } \mathrm{A}, 10.000 .000 \mathrm{Ul} \text {; vit. } \mathrm{D}_{3}, 2.000 .000 \mathrm{UI} \text {; vit. E, } 12,5 \mathrm{~g} \text {; vit } \\
\mathrm{K}_{3}, 2,5 \mathrm{~g} \text {; vit. } \mathrm{B}_{1}, 2,4 \mathrm{~g} \text {; vit. } \mathrm{B}_{2}, 6,0 \mathrm{~g} \text {; vit. } \mathrm{B}_{6}, 3,2 \mathrm{~g} \text {; vit. } \mathrm{B}_{12}, 12 \mathrm{mg} \text {; ácido fólico, } 1,0 \mathrm{~g} \text {; pantotenatc } \\
\text { de Ca, } 12,5 \mathrm{~g} \text {; niacina, } 30 \mathrm{~g} \text {; selelenio, } 0,2 \mathrm{~g} \text {; BHT, } 15 \mathrm{~g} \text {. } \\
{ }^{2} \text { Concentração por kg de produto: manganês, } 65 \mathrm{~g} \text {; cobre, } 12 \mathrm{~g} \text {; zinco, } 50 \mathrm{~g} \text {; ferro, } 40 \mathrm{~g} \text {; iodo, } \\
\mathrm{g} \text { g. }\end{array}$} \\
\hline
\end{tabular}




\subsection{Variáveis analisadas}

\subsubsection{Desempenho}

Nos períodos de um a sete, sete a 21 e 21 a 42 dias de idade das aves foram controlados o consumo de ração, o peso vivo, a conversão alimentar e a viabilidade criatória. Aos 21 dias de idade, as aves foram pesadas, sendo que as cinco aves com peso mais próximo do peso médio da parcela foram selecionadas e transferidas para baterias de crescimento onde foram criadas até 42 dias de idade. Do primeiro ao sétimo dia de idade das aves foi feito o controle diário do consumo de ração sendo posteriormente calculado o consumo corrigido por ave nessa fase de criação.

\subsubsection{Alometria dos órgãos do sistema digestório e saco vitelino}

Do primeiro ao sétimo dia de experimento e ao $21^{\circ}$ e $42^{\circ}$ dia de idade das aves foram escolhidas aleatoriamente duas aves por parcela sendo, essas pesadas e abatidas por deslocamento cervical, os órgãos retirados para mensurações do comprimento do intestino delgado e o peso dos órgãos do sistema digestório (proventrículo, moela, intestino delgado, pâncreas e fígado), assim como, o peso do saco vitelino. Posteriormente, foram calculados os pesos relativos dos órgãos em função do peso vivo e a relação peso do intestino delgado sobre o comprimento do mesmo.

Considerou-se como unidade experimental para a fase de um a sete dias de idade a média dos pesos relativos durante esse período sendo composta por 14 aves por repetição. Adotou-se essa metodologia com o propósito de se ter uma maior confiabilidade dos dados. Para as fases subseqüentes considerouse como uma unidade experimental a média das duas aves por repetição.

O peso da moela foi registrado após ser aberta por incisão longitudinal 
para a retirada do conteúdo. O intestino delgado foi retirado e medido o comprimento $(\mathrm{cm})$. Feito isso, retirou-se o conteúdo intestinal aplicando-se uma pressão sobre as paredes dos intestinos para mensuração do peso vazio. 0 pâncreas foi retirado da alça duodenal e colocado em copo plástico previamente tarado, assim como o saco vitelino.

\subsection{Análise estatística}

Os dados de desempenho e alometria dos órgãos ao $21^{\circ}$ e $42^{\circ}$ dia foram submetidos à análise de variância pelo PROC GLM (General Linear Models) do programa Statistical Analysis System (SAS, 1996). As médias obtidas foram comparadas por contrastes ortogonais sendo que o modelo associado ao delineamento utilizado foi:

$$
Y_{i j}=\mu+t_{i}+e_{i j} ;
$$

Onde:

$i=$ tratamentos (testemunha, glicose, sacarose, amido de milho, amido de mandioca e lactose);

$$
\begin{aligned}
& \mathrm{j}=\text { repetição }(1,2,3 \text { e } 4) ; \\
& Y_{i j}=\text { resposta observada no i-ésimo tratamento e j-ésima repetição; } \\
& \mu=\text { média geral; } \\
& t_{i}=\text { efeito do i-ésimo tratamento; } \\
& e_{i j}=\text { erro aleatório no i-ésimo tratamento e j-ésima repetição; }
\end{aligned}
$$

Para análise dos dados de alometria dos órgãos do primeiro ao sétimo dia utilizou-se a idade das aves como covariável. Para essa análise o modelo foi:

$$
Y_{i j}=\mu+t_{i}+b_{1} x+b_{2} x^{2}+e_{i j} ;
$$

Onde:

$i=$ tratamentos (testemunha, glicose, sacarose, amido de milho, amido de mandioca e lactose); 
$\mathrm{j}=$ repetição (1, 2, 3 e 4);

$Y_{i j}=$ resposta observada no i-ésimo tratamento e j-ésima repetição;

$\mu=$ média geral;

$t_{i}=$ efeito do i-ésimo tratamento;

$b_{1}, b_{2}=$ coeficiente de regressão linear e quadrático, respectivamente, associados ao efeito da idade;

$\mathrm{x}, \mathrm{x}^{2}$ = efeito linear e quadrático, respectivamente, da covariável idade;

$e_{i j}=$ erro aleatório no i-ésimo tratamento e j-ésima repetição;

Foram considerados significativos os contrastes com nível de significância menor que 0,10 pelo teste $F$. 


\section{RESULTADOS E DISCUSSÃO}

\subsection{Desempenho}

Os valores médios dos tratamentos para as variáveis consumo de ração, conversão alimentar e viabilidade criatória de um a sete, sete a 21 e 21 a 42 dias de idade das aves, assim como os pesos vivos ao sétimo, $21^{\circ}$ e $42^{\circ}$ dia de idade são apresentados na Tabela 4. Os valores originais dos dados de desempenho são apresentados nas Tabelas A1, A2, A3, A4 e A5, no apêndice.

Observou-se um efeito de tratamento para variável consumo de ração das aves de um a sete dias de idade ( $P=0,0062)$, havendo também um efeito de tratamentos para peso vivo aos sete dias de idade $(P=0,0975)$ e para conversão alimentar na fase de 21 a 42 dias de idade $(P=0,0163)$. A variável viabilidade criatória não foi afetada significativamente por nenhum dos tratamentos em nenhuma das fases de criação das aves, assim como o consumo de ração de sete a 21 e de 21 a 42 dias de idade. Aos 21 e 42 dias de idade não houve diferença significativa entre os tratamentos para o peso vivo das aves. A conversão alimentar das aves nos períodos de um a sete e de sete a 21 dias de idade também não diferiu entre os tratamentos aplicados.

Pela análise de contrates tem-se que para consumo de ração das aves de um a sete dias de idade o tratamento testemunha diferiu dos demais sendo que aquele teve menor consumo; as aves do tratamento que utilizou glicose como fonte de carboidrato obtiveram um maior consumo de ração diferindo do tratamento com sacarose. No contraste entre os diferentes 
Tabela 4. Valores médios do desempenho de frangos de corte de 1 a 7,7 a 21 e 21 a 42 dias de idade, valores de $F$, coeficiente de variação (CV) e comparação de médias por contrastes.

\begin{tabular}{|c|c|c|c|c|c|c|c|c|c|c|c|c|}
\hline \multirow{2}{*}{ Tratamentos } & \multicolumn{3}{|c|}{ Consumo de Ração } & \multicolumn{3}{|c|}{ Peso Vivo } & \multicolumn{3}{|c|}{ Conversão Alimentar } & \multicolumn{3}{|c|}{ Viabilidade Criatória } \\
\hline & $1-7$ & $7-21$ & $21-42$ & 7 & 21 & 42 & $1-7$ & $7-21$ & $21-42$ & $1-7$ & $7-21$ & $21-42$ \\
\hline Testemunha & 141,1 & 877,6 & 2884 & 174,9 & 786,2 & 2394 & 1,11 & 1,41 & 1,80 & 92,9 & 84,7 & 100,0 \\
\hline Glicose & 157,4 & 905,2 & 2974 & 189,7 & 816,3 & 2438 & 1,11 & 1,45 & 1,83 & 94,6 & 90,9 & 100,0 \\
\hline Sacarose & 149,3 & 893,9 & 2915 & 182,6 & 786,8 & 2343 & 1,11 & 1,43 & 1,90 & 92,9 & 84,1 & 100,0 \\
\hline Amido Milho & 142,1 & 869,6 & 2942 & 180,1 & 794,5 & 2408 & 1,07 & 1,40 & 1,84 & 94,6 & 86,4 & 100,0 \\
\hline A. Mandioca & 147,2 & 934,6 & 2879 & 184,0 & 822,3 & 2373 & 1,08 & 1,47 & 1,85 & 94,6 & 97,9 & 100,0 \\
\hline Lactose & 142,5 & 887,2 & 2931 & 179,8 & 792,1 & 2398 & 1,08 & 1,42 & 1,84 & 92,9 & 86,4 & 100,0 \\
\hline $\begin{array}{c}\text { Média } \\
\text { Contrastes }\end{array}$ & 146,6 & 894,7 & 2921 & 181,8 & 799,7 & $\begin{array}{c}2392 \\
\text { Probabi }\end{array}$ & $\begin{array}{r}1,09 \\
\text { lidade }\end{array}$ & 1,43 & 1,84 & 93,7 & 88,4 & 100,0 \\
\hline $\begin{array}{l}\text { Testemunha } \\
\text { vs Outros }\end{array}$ & 0,0491 & ns & ns & 0,0342 & ns & ns & ns & ns & 0,0215 & ns & ns & ns \\
\hline $\begin{array}{l}\text { A. Milho vs } \\
\text { A.Mandioca }\end{array}$ & ns & 0,0300 & ns & ns & ns & ns & ns & 0,0434 & ns & ns & ns & ns \\
\hline $\begin{array}{l}\text { Glicose vs } \\
\text { Sacarose }\end{array}$ & 0,0598 & ns & ns & ns & ns & ns & ns & ns & 0,0056 & ns & ns & ns \\
\hline $\begin{array}{l}\text { Amidos vs } \\
\text { Açúcares } \\
\text { Lactose vs }\end{array}$ & 0,0066 & ns & ns & ns & ns & ns & 0,0590 & ns & ns & ns & ns & ns \\
\hline $\begin{array}{l}\text { Amidos e } \\
\text { Açúcares }\end{array}$ & 0,0569 & ns & ns & ns & ns & ns & ns & ns & ns & ns & ns & ns \\
\hline$P^{3}>F$ & 0,0062 & 0,2684 & 0,8687 & 0,0975 & 0,5201 & 0,6911 & 0,4071 & 0,3160 & 0,0163 & 0,8958 & 0,6729 & 1,0000 \\
\hline CV (\%) & 3,89 & 4,36 & 4,11 & 3,67 & 4,18 & 3,44 & 3,06 & 3,41 & 1,83 & 3,70 & 14,85 & 0,00 \\
\hline
\end{tabular}


tipos de amido não se observou diferença, mas quando compararam-se os tratamentos que utilizaram fontes de amido (amido de milho e amido de mandioca) versus os tratamentos que utilizaram açúcares mais simples (glicose e sacarose) observa-se que os tratamentos que utilizaram açúcares mais simples tiveram um maior consumo de ração de um a sete dias de idade. $O$ carboidrato lactose, em contraste com os amidos e açúcares, resultou em um menor consumo de ração pelas aves na fase pré-inicial. Segundo Noy \& Sklan (1995) o consumo de ração pode ser controlado pela capacidade da ave em digerir o alimento de tal forma que o consumo não exceda a capacidade digestiva. Isso explicaria em parte o maior consumo de ração pelas aves que receberam os carboidratos de maior digestibilidade (glicose, sacarose, amido de milho e amido de mandioca) em relação às aves que receberam ração testemunha e a ração com lactose.

O maior consumo de ração de um a sete dias de idade pelas aves que receberam algum carboidrato como tratamento acarretou num maior peso vivo ao sete dias pelas mesmas. No entanto, observou-se uma piora na conversão alimentar de um a sete dias das aves para os tratamentos que utilizaram açúcares mais simples em contraste com os tratamentos que utilizaram os amidos.

De sete a 21 dias de idade o contraste entre os amidos evidenciou um maior consumo de ração para as aves que receberam amido de mandioca, resultando numa pior conversão alimentar para este tratamento nessa fase, uma vez que o peso vivo não foi alterado nas mesmas proporções.

A conversão alimentar de 21 a 42 dias de idade das aves foi afetada pelos tratamentos sendo que as aves do tratamento testemunha apresentaram melhor conversão alimentar, mas isso ocorreu em detrimento de um menor consumo e menor ganho de peso das aves nesse tratamento. Houve também uma melhora de $4 \%$ na conversão alimentar das aves do tratamento que utilizou a glicose em contraste com a sacarose; este fato só foi observado de forma estatisticamente significativa na última fase. No entanto, as aves do 
tratamento que utilizou glicose já vinham tendo, nas outras fases, um maior peso vivo (aproximadamente $4 \%$ maior) e um maior consumo de ração (aproximadamente $3 \%$ maior) do que o tratamento com sacarose.

\subsection{Alometria dos órgãos do sistema digestório e do saco vitelino}

\subsubsection{Saco Vitelino}

Os dados referentes ao peso relativo do saco vitelino de um a sete dias são apresentados na Tabela 4 e Figura 1. Os valores originais dos dados do peso relativo do saco vitelino são apresentados na Tabela A6, no apêndice.

Não foi observado efeito de tratamento $(P=0,4532)$ para o peso relativo

do saco vitelino das aves. É provável que não se tenha observado efeito de tratamento para essa variável devido ao alto coeficiente de variação $(49,59 \%)$ que é uma característica intrínseca do saco vitelino.

No entanto, é importante ressaltar que no momento da coleta do saco vitelino, principalmente a partir do quarto dia de idade, observou-se que as aves com menor peso (pintinho refugo) eram as que tinham maior saco vitelino, sugerindo dessa forma a função do saco vitelino em fornecer nutrientes e conseqüentemente promover o desenvolvimento da ave, além da proteção imunológica ao pintinho que é passada de forma passiva durante a incubação e os primeiros dias de vida do pintinho (Vieira \& Moran Jr., 1999a).

A idade teve um efeito quadrático $(P<0,0001)$ sobre o peso relativo do saco vitelino. Segundo a análise da equação de regressão (Figura 1), o ponto em que o peso relativo do saco vitelino foi aproximadamente zero, ou seja, quando houve a total absorção do saco vitelino ocorreu entre o quinto e sexto dia. A máxima taxa de absorção do saco vitelino em relação ao peso vivo da ave ocorreu entre o primeiro e segundo dia de idade das aves; entre o segundo e quarto dia de idade da ave observa-se uma menor absorção do saco vitelino 
Tabela 5. Valores médios do peso relativo do saco vitelino (\% do peso vivo) de 1 a 7 dias de idade, valores de $F$, coeficiente de variação $(C V)$ e comparação de médias por contrastes.

\begin{tabular}{lc}
\hline \multicolumn{1}{c}{ Tratamentos } & Peso Relativo (\%PV) \\
& 1 a $7 \mathrm{~d}$ \\
\hline Testemunha & 1,597 \\
Glicose & 1,498 \\
Sacarose & 1,811 \\
Amido Milho & 1,814 \\
Amido Mandioca & 1,600 \\
Lactose & 1,474 \\
Média $\quad$ Contrastes & 1,632 \\
& Probabilidade \\
Testemunha vs. Outros & 1 a $7 \mathrm{~d}$ \\
A. Milho vs. A. Mandioca & $\mathrm{ns}$ \\
Glicose vs. Sacarose & $\mathrm{ns}$ \\
Amidos vs. Açúcares & $\mathrm{ns}$ \\
Lactose vs. Amidos e Açúcares & $\mathrm{ns}$ \\
P $>$ F & $\mathrm{ns}$ \\
CV (\%) & 0,4532 \\
\hline
\end{tabular}
ns - não significativo $(P>0,10)$.

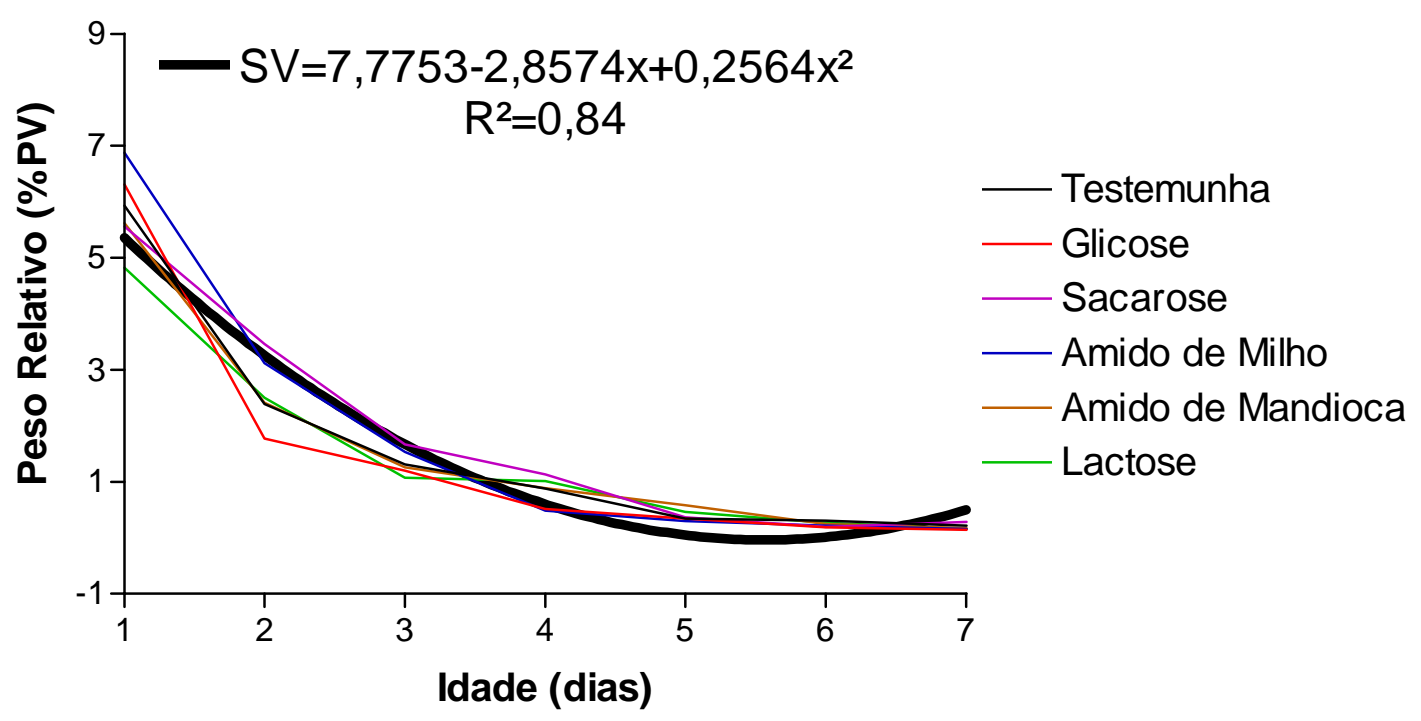

Figura 1 - Peso relativo do saco vitelino (\% do peso vivo) de 1 a 7 dias de idade para cada tratamento e a equação geral de regressão do peso relativo do saco vitelino (SV) em função da idade $(x)(P<0,0001)$. 
da ave sendo que a partir do quarto dia o saco vitelino representava menos que $1 \%$ do peso vivo da ave.

\subsubsection{Proventrículo}

Os pesos relativos médios do proventrículo de um a sete e aos 21 e 42 dias de idade são apresentados na Tabela 6 . Na Figura 2 são apresentadas as curvas de desenvolvimento do peso relativo do proventrículo de um a sete dias de idade para os respectivos tratamentos assim como a curva de crescimento do proventrículo em relação ao peso vivo da ave em função da idade. Os valores originais dos dados do peso relativo do proventrículo são apresentados na Tabela $A 7$, no apêndice.

Não foi observado efeito de tratamento sobre o peso relativo do proventrículo para nenhuma idade. Observou-se apenas um maior peso relativo do proventrículo aos 21 dias para o tratamento testemunha em relação aos outros tratamentos. Já aos 42 dias de idade o tratamento que utilizou amido de milho apresentou um maior peso relativo do proventrículo quando contrastado com o tratamento que utilizou amido de mandioca.

O fato de não ter havido efeito significativo de tratamento para o peso relativo do proventrículo não causa surpresa visto que o proventrículo tem pouca influência sobre a digestão de carboidratos havendo apenas uma pequena hidrólise química pelo $\mathrm{HCl}$ produzido no proventrículo.

A idade teve um efeito quadrático $(P<0,0001)$ no período de um a sete dias sobre o desenvolvimento do proventrículo (Figura 2). O proventrículo teve a maior relação peso do órgão pelo peso vivo da ave próximo ao quarto dia de idade tendo em seguida uma acentuada queda no peso relativo. 
Tabela 6. Valores médios do peso relativo do proventrículo (\% do peso vivo) de 1 a 7, 21 e 42 dias de idade, valores de $F$, coeficiente de variação (CV) e comparação de médias por contrastes.

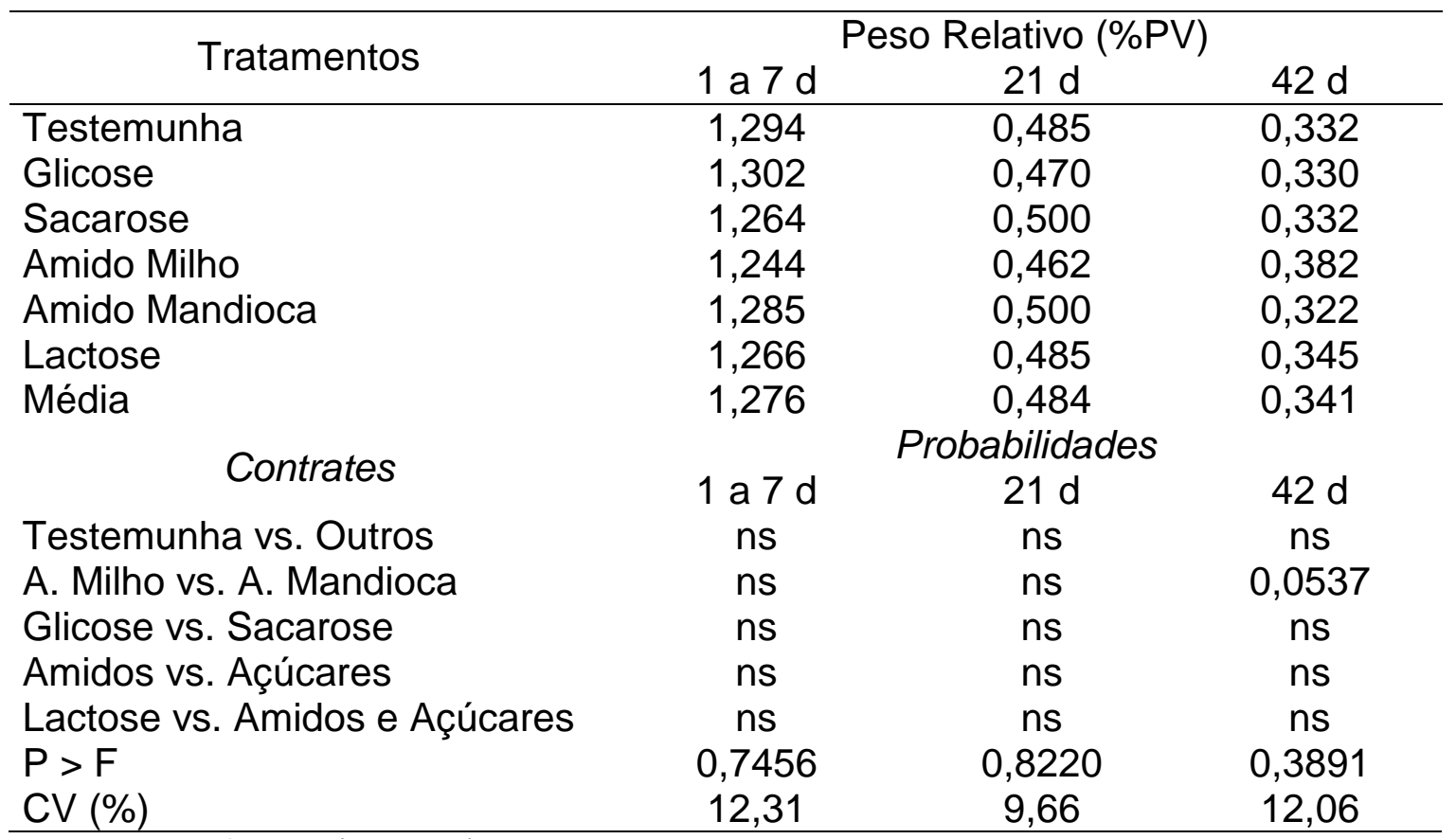
ns - não significativo $(P>0,10)$.

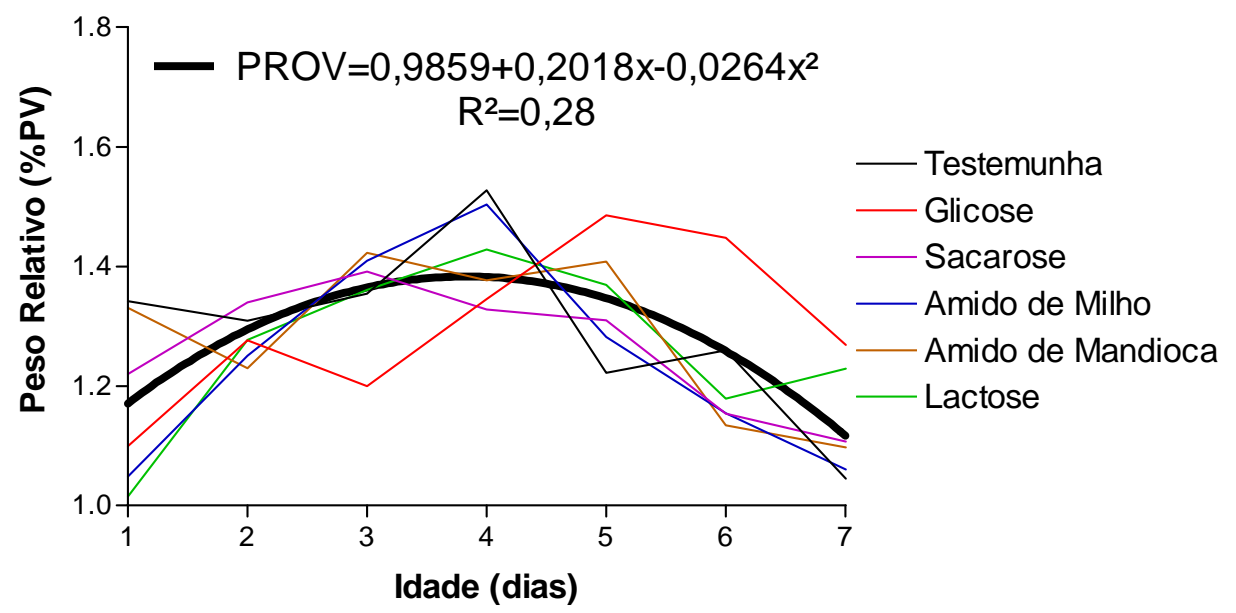

Figura 2 - Peso relativo do proventrículo (\% do peso vivo) de 1 a 7 dias de idade para cada tratamento e a equação geral de regressão do peso relativo do proventrículo (PROV) em função da idade $(x)(P<0,0001)$. 


\subsubsection{Moela}

As médias dos pesos relativos da moela de um a sete, aos 21 e 42 dias de idade das aves são apresentados na Tabela 7. As curvas de desenvolvimento dos pesos relativos da moela para cada tratamento são apresentados na Figura 3, assim como, a curva de regressão da moela em relação ao peso vivo da ave em função da idade. Os valores originais dos dados do peso relativo da moela são apresentados na Tabela A8, no apêndice.

De um a sete dias de idade observou-se um efeito de tratamento $(P=0,0006)$ sobre o peso relativo da moela das aves. As aves do tratamento testemunha tiveram um maior peso relativo de moela quando comparado com as aves dos demais tratamentos. Da mesma forma, as aves do tratamento que recebeu lactose também tiveram um maior peso relativo que as aves dos demais tratamentos que receberam algum tipo de carboidrato. O tratamento que recebeu glicose quando contrastado com o tratamento que recebeu sacarose causou um menor peso relativo da moela das aves.

$O$ peso relativo da moela pode ter sido afetado, em parte, pela granulometria média das rações, visto que a glicose, o amido de milho e o amido de mandioca são ingredientes mais finamente moídos que o milho o qual foi o ingrediente mais afetado pela inclusão dos carboidratos na formulação das rações. A lactose possuía uma granulometria semelhante à glicose e os amidos, no entanto ela foi adicionada à ração na razão de apenas $5 \%$ enquanto os outros ingredientes foram adicionados em média a 15\%. Krabbe (2000) estudando o efeito do tamanho de partícula sobre o peso relativo da moela na fase pré-inicial encontrou efeito de tratamento, sendo que os tratamentos que receberam ração com maior tamanho de partícula tiveram maior peso relativo de moela. Pode-se entender com isso que ingredientes mais finos ficam menos tempo na moela por exigir uma menor maceração do alimento acarretando num menor peso de moela. 
Tabela 7. Valores médios do peso relativo da moela (\% do peso vivo) de 1 a 7 , 21 e 42 dias de idade, valores de $F$, coeficiente de variação $(C V)$ e comparação de médias por contrastes.

\begin{tabular}{lccc}
\hline \multicolumn{1}{c}{ Tratamentos } & \multicolumn{3}{c}{ Peso Relativo (\%PV) } \\
& 1 a 7 d & $21 \mathrm{~d}$ & $42 \mathrm{~d}$ \\
\hline Testemunha & 5,168 & 2,405 & 1,427 \\
Glicose & 4,835 & 2,235 & 1,550 \\
Sacarose & 5,068 & 2,372 & 1,407 \\
Amido Milho & 5,008 & 2,657 & 1,447 \\
Amido Mandioca & 4,989 & 2,227 & 1,300 \\
Lactose & 5,182 & 2,310 & 1,437 \\
Média & 5,042 & 2,368 & 1,428 \\
\multicolumn{1}{c}{ Contrates } & $1 \mathrm{a} 7 \mathrm{~d}$ & Probabilidades & \\
\multicolumn{1}{l}{ Testemunha vs. Outros } & 0,0234 & $21 \mathrm{~d}$ & $42 \mathrm{~d}$ \\
A. Milho vs. A. Mandioca & $\mathrm{ns}$ & $\mathrm{ns}$ & $\mathrm{ns}$ \\
Glicose vs. Sacarose & 0,0068 & $\mathrm{~ns}$ & $\mathrm{~ns}$ \\
Amidos vs. Açúcares & $\mathrm{ns}$ & $\mathrm{ns}$ & $\mathrm{ns}$ \\
Lactose vs. Amidos e Açúcares & 0,0025 & $\mathrm{~ns}$ & $\mathrm{~ns}$ \\
P > F & 0,0006 & 0,1039 & $\mathrm{~ns}$ \\
CV (\%) & 6,33 & 9,11 & 11,23 \\
\hline
\end{tabular}
ns - não significativo $(P>0,10)$.

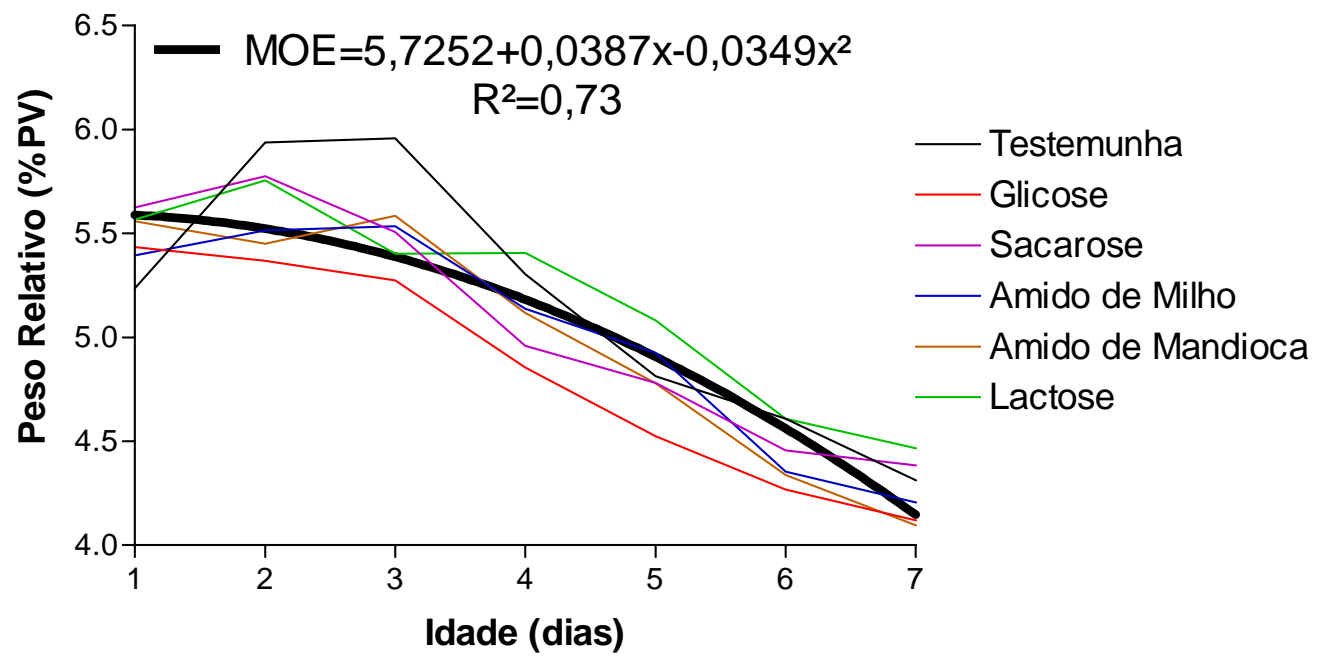

Figura 3 - Peso relativo da moela (\% do peso vivo) de 1 a 7 dias de idade para cada tratamento e a equação geral de regressão do peso relativo da moela (MOE) em função da idade $(x)(P<0,0001)$. 
Aos 21 dias de idade não houve efeito de tratamento $(P=0,1039)$. Observa-se apenas que as aves do tratamento com amido de milho tiveram maior peso relativo de moela quando contrastou-se com as aves do tratamento com amido de mandioca, mas até o momento não foi encontrada na literatura uma explicação para esse fato.

A idade teve um efeito quadrático $(P<0,0001)$ sobre o desenvolvimento da moela (Figura 3). A moela é o órgão do sistema digestório que tem maior representatividade no peso vivo da ave ao primeiro dia de idade e é o órgão que tem menor desenvolvimento durante todo período de vida da ave.

\subsubsection{Intestino Delgado}

\subsubsection{Peso Relativo}

Os pesos relativos do intestino delgado das aves de um a sete dias e aos 21 e 42 dias de idade são apresentados na Tabela 8. Na Figura 4 são apresentadas as curvas de desenvolvimento do peso relativo do intestino de um a sete dias de idade para os respectivos tratamentos assim como a curva de regressão para o efeito de idade. Os valores originais dos dados do peso relativo do intestino delgado são apresentados na Tabela A9, no apêndice.

Houve efeito de tratamento para o peso relativo do intestino de um a sete dias $(P=0,0025)$ e aos 42 dias $(P=0,0427)$ de idade das aves. Do primeiro ao sétimo dia de idade, as aves dos tratamentos que receberam algum tipo de carboidrato obtiveram, em média, um maior peso relativo do intestino quando contrastado com o tratamento testemunha. As aves do tratamento que recebeu sacarose foram as que tiveram maior peso relativo de intestino delgado sendo que quando contrastado com o tratamento que recebeu glicose essa diferença foi significativa. $O$ tratamento das aves com lactose levou a um maior peso relativo do intestino quando comparado com as aves dos tratamentos que receberam algum tipo de carboidrato. 
Tabela 8. Valores médios do peso relativo do intestino (\% do peso vivo) de 1 a 7,21 e 42 dias de idade, valores de F, coeficiente de variação (CV) e comparação de médias por contrastes.

\begin{tabular}{|c|c|c|c|}
\hline \multirow{2}{*}{ Tratamentos } & \multicolumn{3}{|c|}{ Peso Relativo (\%PV) } \\
\hline & $1 \mathrm{a} 7 \mathrm{~d}$ & $21 d$ & $42 d$ \\
\hline Testemunha & 4,211 & 2,940 & 1,982 \\
\hline Glicose & 4,146 & 2,912 & 2,087 \\
\hline Sacarose & 4,606 & 2,987 & 2,165 \\
\hline Amido Milho & 4,489 & 2,820 & 1,987 \\
\hline Amido Mandioca & 4,334 & 2,980 & 1,982 \\
\hline Lactose & 4,632 & 2,957 & 2,337 \\
\hline Média & 4,403 & 2,933 & 2,090 \\
\hline Contractec & & Probabilidad & \\
\hline comilastes & 1 a $7 d$ & $21 \mathrm{~d}$ & $42 \mathrm{~d}$ \\
\hline Testemunha vs. Outros & 0,0451 & ns & ns \\
\hline A. Milho vs. A. Mandioca & ns & ns & ns \\
\hline Glicose vs. Sacarose & 0,0021 & ns & ns \\
\hline Amidos vs. Açúcares & ns & ns & ns \\
\hline Lactose vs. Amidos e Açúcares & 0,0426 & ns & 0,0072 \\
\hline$P>F$ & 0,0025 & 0,8377 & 0,0427 \\
\hline CV (\%) & 12,50 & 6,59 & 7,95 \\
\hline
\end{tabular}
ns - não significativo $(P>0,10)$.

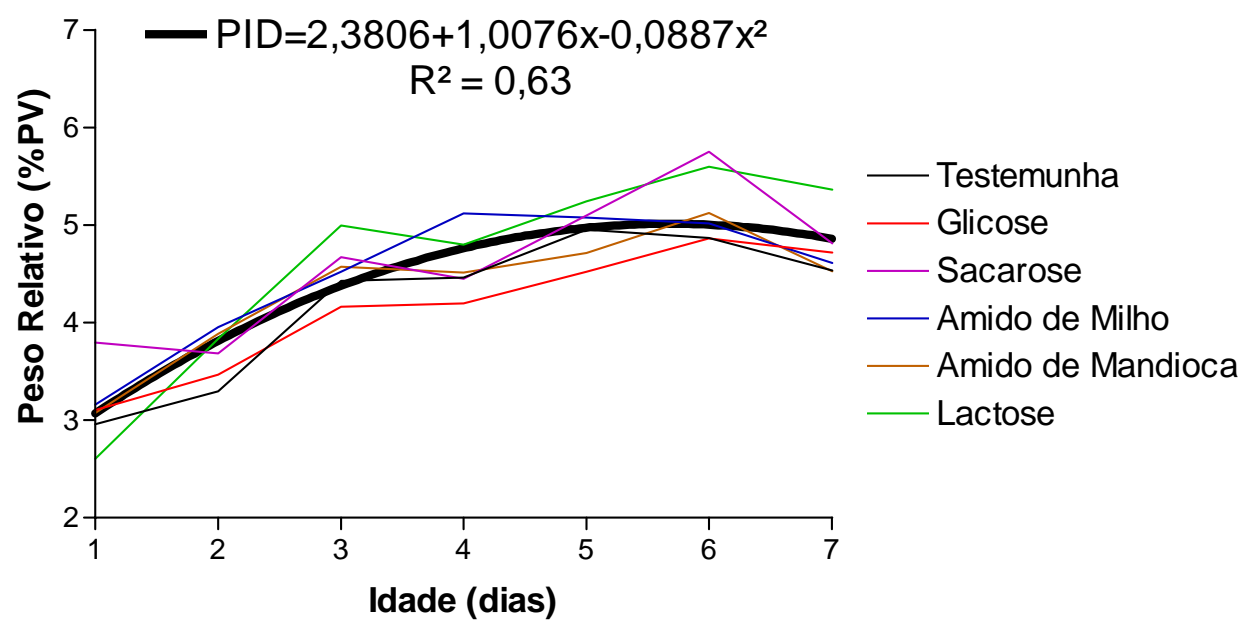

Figura 4 - Peso relativo do intestino delgado (ID) (\% do peso vivo) de 1 a 7 dias de idade para cada tratamento e a equação geral de regressão do peso relativo do ID (PID) em função da idade $(x)(P<0,0001)$. 
Segundo Rosensweig \& Herman (1968) a atividade das dissacaridases pode ser mais afetada pelo uso da sacarose e frutose do que por outros carboidratos como glicose, galactose ou lactose. Isso explica, em parte, o maior peso relativo do intestino delgado para o tratamento que utilizou sacarose do que o tratamento que utilizou glicose.

Aos 42 dias de idade, o peso do intestino delgado das aves que receberam lactose na fase pré-inicial também foi maior que os demais tratamentos que receberam algum tipo de carboidrato. A lactose influenciou o peso relativo do intestino delgado, provavelmente, por ter baixa digestibilidade, visto que, as aves não possuem a enzima lactase. A fermentação da lactose por parte da microbiota intestinal pode ter causado uma irritação da mucosa intestinal o que pode ter aumentado a secreção de muco levando a um maior peso relativo do intestino.

O peso relativo do intestino delgado comportou-se de forma quadrática $(\mathrm{P}<0,0001)$ para o efeito da idade no período de um a sete dias de idade (Figura 4). Nesse mesmo período o maior peso de intestino em relação ao peso vivo da ave ocorreu próximo ao sexto dia de idade. O peso relativo do intestino delgado, após um rápido desenvolvimento até o sexto dia, começa a decair sendo que aos 21 dias de idade da ave, o peso relativo do intestino é similar ao peso relativo do intestino delgado ao primeiro dia de vida da ave.

\subsubsection{Comprimento}

$\mathrm{Na}$ Tabela 9 são apresentados os dados de comprimento do intestino delgado de um a sete e aos 21 e 42 dias de idade das aves. Os valores originais dos dados do comprimento do intestino delgado são apresentados na Tabela A10, no apêndice. 
Tabela 9. Valores médios do comprimento do intestino delgado $(\mathrm{cm})$ de 1 a 7 , 21 e 42 dias de idade, valores de $F$, coeficiente de variação (CV) e comparação de médias por contrastes.

\begin{tabular}{lccc}
\hline \multicolumn{1}{c}{ Tratamentos } & \multicolumn{3}{c}{ Comprimento $(\mathrm{cm})$} \\
& 1 $7 \mathrm{~d}$ & $21 \mathrm{~d}$ & $42 \mathrm{~d}$ \\
\hline Testemunha & 76,50 & 119,75 & 154,37 \\
Glicose & 77,23 & 131,00 & 149,12 \\
Sacarose & 77,30 & 124,25 & 160,87 \\
Amido Milho & 76,20 & 121,50 & 152,37 \\
Amido Mandioca & 76,52 & 128,37 & 152,00 \\
Lactose & 79,77 & 132,50 & 163,75 \\
Média & 77,25 & 127,35 & 155,42 \\
& & Probabilidade & \\
\multicolumn{1}{c}{ Contrastes } & $1 \mathrm{a} 7 \mathrm{~d}$ & $21 \mathrm{~d}$ & $42 \mathrm{~d}$ \\
Testemunha vs. Outros & $\mathrm{ns}$ & 0,0483 & $\mathrm{~ns}$ \\
A. Milho vs. A. Mandioca & $\mathrm{ns}$ & $\mathrm{ns}$ & $\mathrm{ns}$ \\
Glicose vs. Sacarose & $\mathrm{ns}$ & $\mathrm{ns}$ & $\mathrm{ns}$ \\
Amidos vs. Açúcares & $\mathrm{ns}$ & $\mathrm{ns}$ & $\mathrm{ns}$ \\
Lactose vs. Amidos e Açúcares & 0,0049 & $\mathrm{~ns}$ & $\mathrm{~ns}$ \\
P > F & 0,0826 & 0,0775 & 0,6464 \\
CV (\%) & 6,35 & 5,31 & 8,87 \\
\hline
\end{tabular}
ns - não significativo $(P>0,10)$.

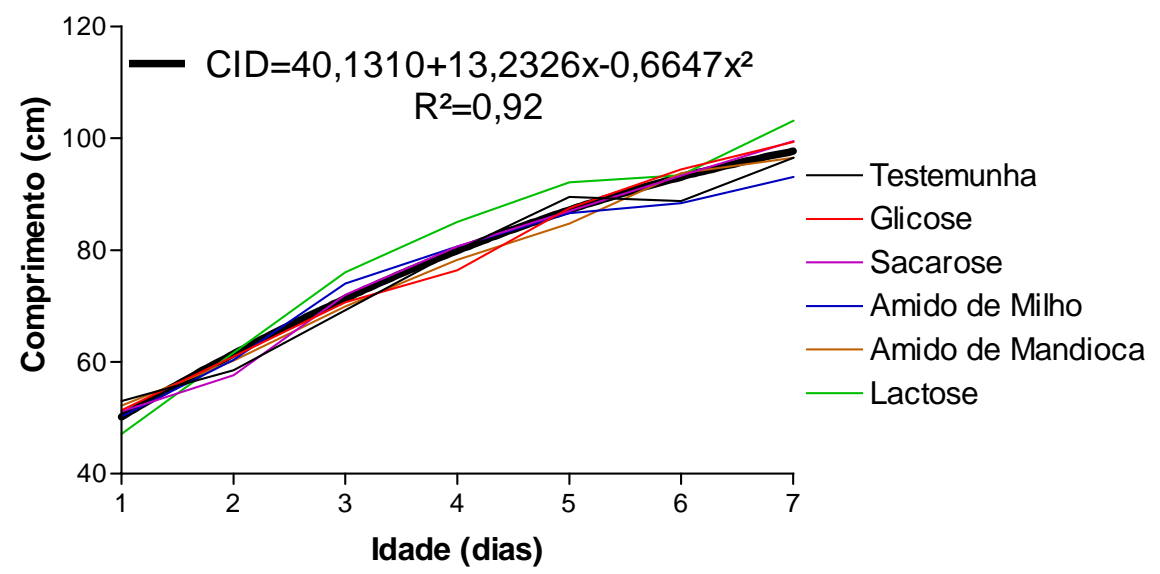

Figura 5 - Comprimento do intestino delgado $(\mathrm{cm})$ de 1 a 7 dias de idade para cada tratamento e a equação geral de regressão do comprimento do intestino delgado (CID) em função da idade $(x) \quad(P<0,0001)$. 
De um a sete dias de idade houve efeito de tratamento para comprimento do intestino delgado $(P=0,0826)$ sendo que o comprimento do intestino delgado das aves que receberam lactose foi maior quando comparados com os tratamentos que utilizaram amidos e açúcares. $O$ efeito de tratamento ocorrido no período de um a sete dias não se perpetuou para as outras fases de criação.

$\mathrm{Na}$ Figura 5 é apresentado o gráfico dos efeitos dos tratamentos sobre o comprimento do intestino delgado juntamente com a curva de regressão para o efeito de idade no período de um a sete dias. Os valores originais dos dados do comprimento do intestino delgado são apresentados na Tabela A10, no apêndice.

Durante quase todo período de um a sete dias o tratamento que recebeu lactose teve um maior comprimento do intestino delgado provavelmente devido a um maior acúmulo de gases, pela fermentação da lactose. Tal fato foi observado até mesmo durante os dias das mensurações dos órgãos. Siddons (1972) estudando o efeito da dieta sobre a atividade das dissacaridases também encontrou um aumento no comprimento do intestino quando utilizou lactose durante 24 dias de alimentação dos pintinhos.

$A$ idade teve efeito quadrático $(P<0,0001)$ sobre o comprimento do intestino delgado e ao sétimo dia essa medida já correspondia a 2/3 do comprimento final aos 42 dias de idade.

\subsubsection{Relação Peso:Comprimento}

$\mathrm{Na}$ Tabela 10 são apresentados os dados referentes à relação do peso:comprimento do intestino delgado $(\mathrm{g} / \mathrm{cm})$ de um a sete, e aos 21 e 42 dias de idade das aves. Os valores originais dos dados da relação peso:comprimento do intestino delgado são apresentados na Tabela A11, no apêndice. 
Tabela 10. Valores médios da relação do peso do Intestino Delgado (ID) pelo comprimento do mesmo $(\mathrm{g} / \mathrm{cm})$ de 1 a 7,21 e 42 dias de idade, valores de $F$, coeficiente de variação $(\mathrm{CV})$ e comparação de médias por contrastes.

\begin{tabular}{lccc}
\hline \multicolumn{1}{c}{ Tratamentos } & \multicolumn{3}{c}{ Relação Peso:Comprimento do ID $(\mathrm{g} / \mathrm{cm})$} \\
& $1 \mathrm{a} 7 \mathrm{~d}$ & $21 \mathrm{~d}$ & $42 \mathrm{~d}$ \\
\hline Testemunha & 0,0603 & 0,1900 & 0,3075 \\
Glicose & 0,0617 & 0,1850 & 0,3425 \\
Sacarose & 0,0659 & 0,1800 & 0,3150 \\
Amido Milho & 0,0627 & 0,1775 & 0,3100 \\
Amido Mandioca & 0,0624 & 0,1975 & 0,3075 \\
Lactose & 0,0620 & 0,1800 & 0,3475 \\
Média & 0,062 & 0,185 & 0,322 \\
\multicolumn{1}{c}{ Contrastes } & $1 \mathrm{a} 7 \mathrm{~d}$ & Probabilidade & \\
Testemunha vs. Outros & $\mathrm{ns}$ & $21 \mathrm{~d}$ & $42 \mathrm{~d}$ \\
A. Milho vs. A. Mandioca & $\mathrm{ns}$ & $\mathrm{ns}$ & $\mathrm{ns}$ \\
Glicose vs. Sacarose & 0,0734 & $\mathrm{~ns}$ & $\mathrm{~ns}$ \\
Amidos vs. Açúcares & $\mathrm{ns}$ & $\mathrm{ns}$ & $\mathrm{ns}$ \\
Lactose vs. Amidos e Açúcares & $\mathrm{ns}$ & $\mathrm{ns}$ & $\mathrm{ns}$ \\
P > F & 0,2776 & 0,7097 & 0,4032 \\
CV (\%) & 14,23 & 10,70 & 10,97 \\
\hline
\end{tabular}

ns - não significativo $(P>0,10)$.

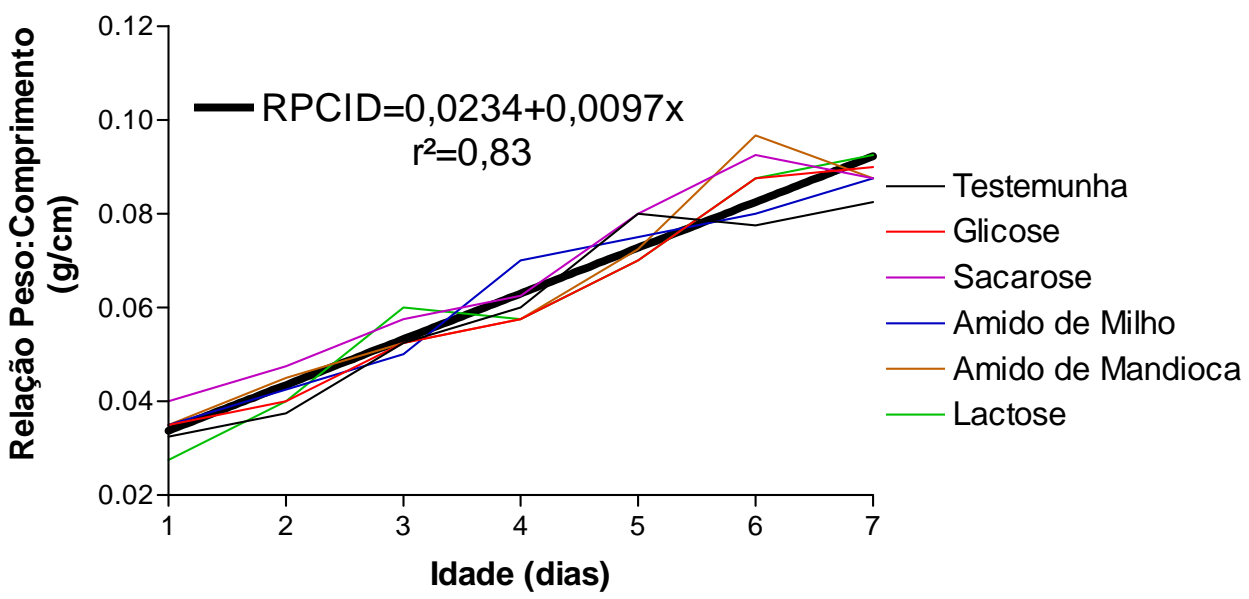

Figura 6 - Relação do peso do intestino delgado pelo comprimento do mesmo $(\mathrm{g} / \mathrm{cm})$ de 1 a 7 dias de idade para cada tratamento e a equação geral de regressão dessa relação (RPCID) em função da idade $(x)$ $(\mathrm{P}<0,0001)$. 
A relação peso:comprimento do intestino delgado fornece, de forma indireta, a espessura da parede do intestino que vai estar ligado a altura e diâmetro das vilosidades do intestino delgado (Corless \& Sell, 1999; Uni et al., 1998).

Não foi observada diferença significativa entre os tratamentos em nenhum dos períodos de coleta. Observa-se apenas uma maior relação peso:comprimento na fase pré-inicial para o tratamento que utilizou sacarose quando comparado com o tratamento com glicose. Uma menor relação peso:comprimento do intestino delgado sugere uma menor capacidade de digestão e absorção pelo intestino (Uni et al., 1998) ou uma maior relação peso:comprimento do intestino delgado pode significar um aumento das vilosidades pela maior produção de dissacaridases devido à utilização de sacarose que estimula a produção dessa enzima.

Pela Figura 6 observa-se que a idade teve um efeito linear sobre a relação peso:comprimento do intestino com uma taxa média de crescimento no período de um a sete dias de aproximadamente $0,01 \mathrm{~g} / \mathrm{cm}$ por dia, evidenciando dessa forma que o trato digestório ainda não atingiu sua maturidade para um completa digestão e absorção.

\subsubsection{Pâncreas}

Os pesos relativos médios do pâncreas das aves de um a sete e aos 21 e 42 dias de idade são apresentados na Tabela 11. Na Figura 7 são apresentados os efeitos dos tratamentos sobre o peso relativo do pâncreas e a curva de regressão para o efeito de idade no período de um a sete dias de idade. Os valores originais dos dados do peso relativo do pâncreas são apresentados na Tabela A12, no apêndice. 
Tabela 11. Valores médios do peso relativo do pâncreas (\% do peso vivo) de 1 a 7, 21 e 42 dias de idade, valores de $F$, coeficiente de variação (CV) e comparação de médias por contrastes.

\begin{tabular}{lccc}
\hline \multicolumn{1}{c}{ Tratamentos } & \multicolumn{3}{c}{ Peso Relativo (\%PV) } \\
& 1 a 7 d & $21 \mathrm{~d}$ & $42 \mathrm{~d}$ \\
\hline Testemunha & 0,439 & 0,352 & 0,195 \\
Glicose & 0,439 & 0,285 & 0,202 \\
Sacarose & 0,453 & 0,313 & 0,205 \\
Amido Milho & 0,462 & 0,293 & 0,222 \\
Amido Mandioca & 0,449 & 0,310 & 0,185 \\
Lactose & 0,451 & 0,275 & 0,212 \\
Média & 0,449 & 0,305 & 0,204 \\
& & Probabilidade & \\
\multicolumn{1}{c}{ Contrastes } & $1 \mathrm{a} 7 \mathrm{~d}$ & $21 \mathrm{~d}$ & $42 \mathrm{~d}$ \\
Testemunha vs. Outros & $\mathrm{ns}$ & 0,0352 & $\mathrm{Ns}$ \\
A. Milho vs. A. Mandioca & $\mathrm{ns}$ & $\mathrm{ns}$ & 0,0030 \\
Glicose vs. Sacarose & $\mathrm{ns}$ & $\mathrm{ns}$ & $\mathrm{Ns}$ \\
Amidos vs. Açúcares & $\mathrm{ns}$ & $\mathrm{ns}$ & $\mathrm{Ns}$ \\
Lactose vs. Amidos e Açúcares & $\mathrm{ns}$ & $\mathrm{ns}$ & $\mathrm{Ns}$ \\
P > F & 0,7707 & 0,2615 & 0,0451 \\
CV (\%) & 14,93 & 15,13 & 7,61 \\
\hline
\end{tabular}
ns - não significativo $(P>0,10)$.

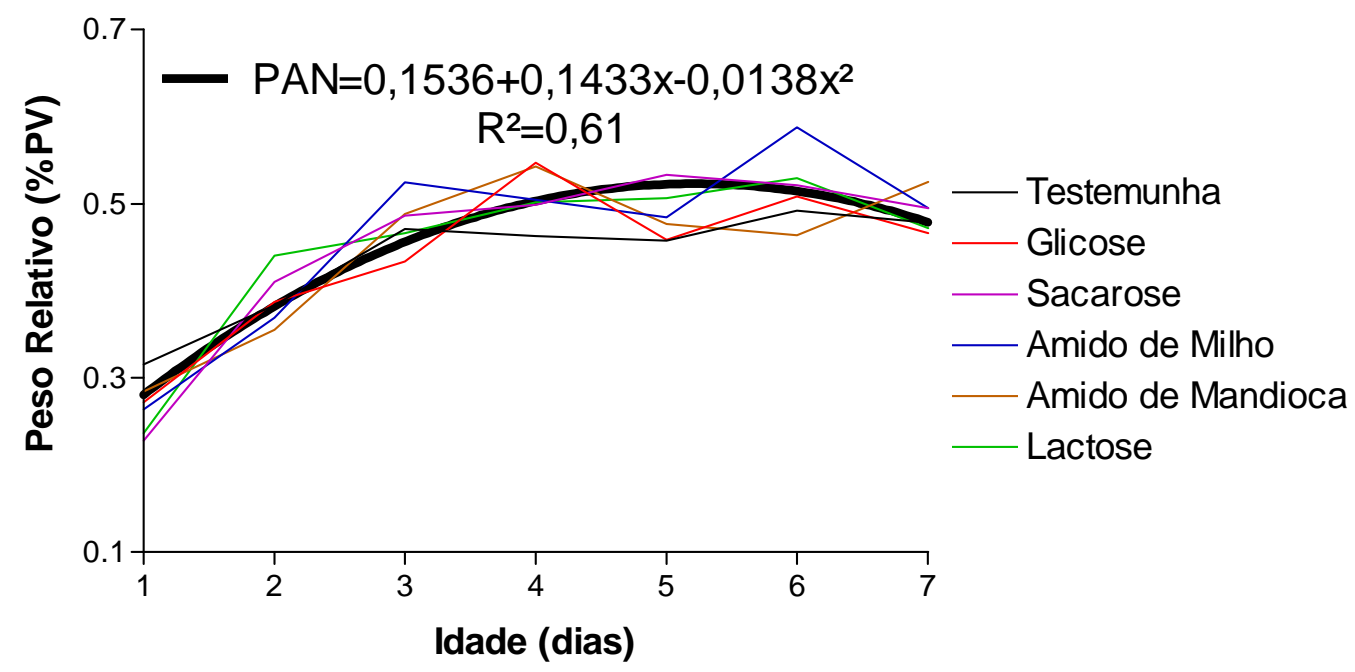

Figura 7 - Peso relativo do pâncreas (\% do peso vivo) de 1 a 7 dias de idade para cada tratamento e a equação geral de regressão do peso relativo do pâncreas (PAN) em função da idade $(x)(P<0,0001)$. 
Do primeiro ao sétimo e no $21^{\circ}$ dia de idade das aves não foi observado efeito de tratamento. Porém, ao $42^{\circ}$ dia verificou-se efeito de tratamento ( $P=0,0451)$ sendo que as aves do tratamento que utilizou o amido de milho de um a sete dias de idade obtiveram um maior peso relativo do pâncreas aos 42 dias de idade que o tratamento que recebeu amido de mandioca. Uma possível explicação para esse fato é que o amido de mandioca tem uma maior quantidade de amilopectina que é mais difícil de ser hidrolisado pela $\alpha$-amilase devido a presença das ramificações com ligações $\alpha-1,6$ que diminui a atividade dessa enzima (Moran Jr., 1982).

Aos 21 dias de idade das aves o tratamento testemunha promoveu um maior peso relativo do pâncreas sendo quase $20 \%$ mais pesado que os outros tratamentos.

A idade teve um efeito quadrático $(P<0,0001)$ sobre o peso relativo do pâncreas no período de um a sete dias (Figura 7). A maior relação do peso do pâncreas pelo peso vivo da ave ocorreu próximo ao quinto dia de idade sendo que após esse período o peso relativo do pâncreas foi decaindo lentamente sendo que o peso relativo do pâncreas ao primeiro dia é aproximadamente igual ao do 210 dia de idade. Observou-se um grande aumento do pâncreas em relação ao peso vivo da ave até o terceiro dia de idade tendendo a uma estabilização após esse período.

\subsubsection{Fígado}

Os pesos relativos médios do fígado das aves de um a sete e aos 21 e 42 dias de idade são apresentados na Tabela 12. Na Figura 8 são apresentados os efeitos dos tratamentos sobre o peso relativo do fígado e a curva de regressão para o efeito de idade no período de um a sete dias de idade. Os valores originais dos dados do peso relativo do fígado são apresentados na Tabela A13, no apêndice. 
Tabela 12. Valores médios do peso relativo do fígado (\% do peso vivo) de 1 a 7 , 21 e 42 dias de idade, valores de $F$, coeficiente de variação (CV) e comparação de médias por contrastes.

\begin{tabular}{|c|c|c|c|}
\hline \multirow{2}{*}{ Tratamentos } & \multicolumn{3}{|c|}{ Peso Relativo (\%PV) } \\
\hline & 1 a $7 d$ & $21 \mathrm{~d}$ & $42 d$ \\
\hline Testemunha & 4,900 & 2,422 & 1,993 \\
\hline Glicose & 5,281 & 2,795 & 1,820 \\
\hline Sacarose & 4,971 & 2,505 & 2,128 \\
\hline Amido Milho & 4,741 & 2,607 & 2,108 \\
\hline Amido Mandioca & 4,849 & 2,265 & 1,990 \\
\hline Lactose & 4,706 & 2,400 & 1,982 \\
\hline Média & 4,908 & 2,499 & 2,003 \\
\hline Contrastes & & Probabilidao & \\
\hline volitiastes & 1 a $7 d$ & $21 \mathrm{~d}$ & $42 d$ \\
\hline Testemunha vs. Outros & ns & ns & ns \\
\hline A. Milho vs. A. Mandioca & ns & ns & ns \\
\hline Glicose vs. Sacarose & 0,0282 & ns & 0,0415 \\
\hline Amidos vs. Açúcares & 0,0010 & ns & ns \\
\hline Lactose vs. Amidos e Açúcares & 0,0227 & ns & ns \\
\hline$P>F$ & 0,0009 & 0,5335 & 0,3334 \\
\hline CV (\%) & 10,66 & 16,01 & 9,89 \\
\hline
\end{tabular}

ns - não significativo $(P>0,10)$.

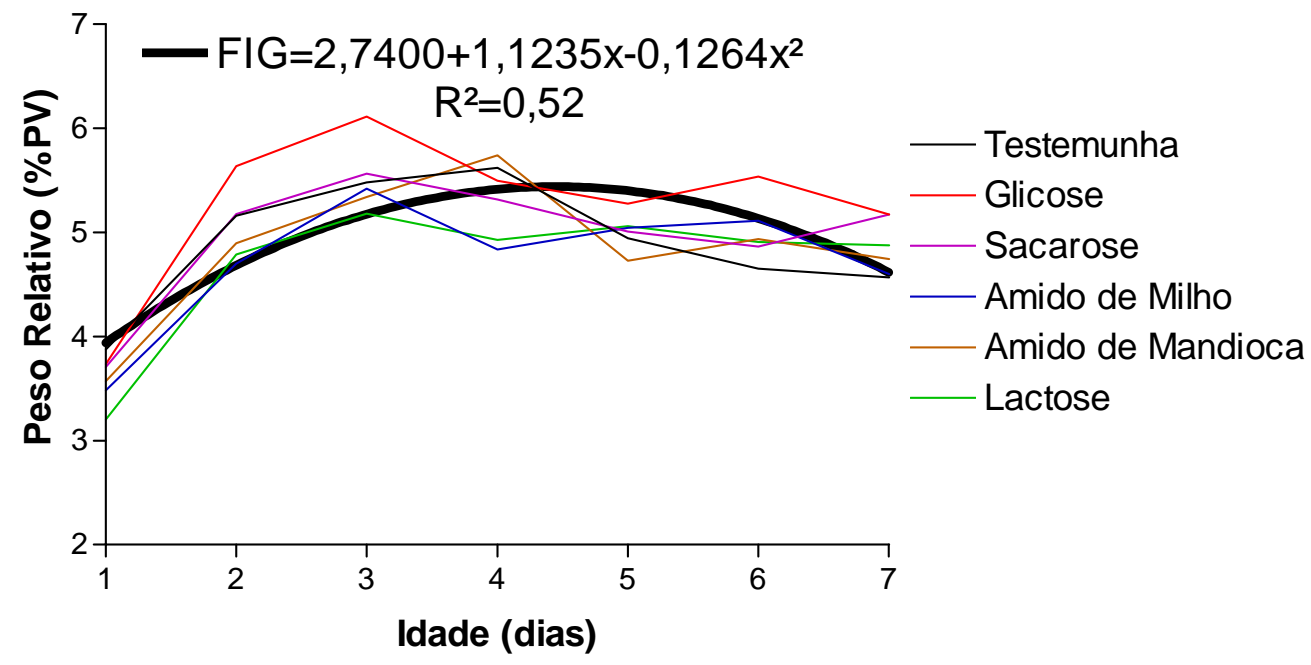

Figura 8 - Peso relativo do fígado (\% do peso vivo) de 1 a 7 dias de idade para cada tratamento e a equação geral de regressão do peso relativo do fígado ( $F I G)$ em função da idade $(x)(P<0,0001)$. 
Observou-se efeito de diferentes tratamentos $(P=0,0009)$ sobre o peso relativo do fígado das aves no período de um a sete dias de idade. As aves do tratamento que receberam glicose obtiveram maior peso relativo de fígado sendo que quando esse tratamento foi contrastado com o tratamento que utilizou sacarose essa diferença foi significativa. No contraste entre os tratamentos que utilizaram amidos versus tratamentos que utilizaram açúcares, o peso relativo do fígado das aves foi maior para aquelas que utilizaram açúcares. As aves do tratamento com lactose tiveram menor peso relativo do fígado e quando em contraste com os amidos e açúcares essa diferença foi significativa.

Como se pode observar na Figura 8, o tratamento que utilizou glicose de um a sete dias de idade proporcionou um maior peso relativo do fígado das aves durante esse mesmo período com exceção do quarto dia onde o peso relativo do fígado teve uma pequena queda. As diferenças entre os tratamentos para o peso relativo de fígado foram mais explícitas no segundo e terceiro dia de idade, provavelmente devido a menor capacidade do sistema digestório em digerir amido e dissacarídeos nos primeiros dias de vida (Noy \& Sklan, 1995). Dessa forma, o tratamento que forneceu glicose às aves propiciou um maior peso relativo de fígado na fase pré-inicial possivelmente em função do acúmulo de glicogênio hepático. O peso relativo do fígado do tratamento com glicose foi aproximadamente $7 \%$ maior que o tratamento testemunha, valor próximo ao citado por Guyton (1992), que diz que o glicogênio pode aumentar até um total de $6 \%$ da massa hepática.

Aos 42 dias de idade, as aves do tratamento que utilizou glicose de um a sete dias tiveram um menor peso relativo de fígado em contraste com o tratamento que utilizou sacarose e contrariando o que havia ocorrido na fase pré-inicial, quando o tratamento com glicose teve o maior peso relativo de fígado. 
O peso relativo do fígado de um a sete dias apresentou um efeito quadrático para idade $(\mathrm{P}<0,0001)$ sendo que a maior relação peso do fígado pelo peso vivo da ave ocorreu próximo ao quarto dia de idade (Figura 8). 


\subsection{Considerações Gerais}

A utilização da técnica de abate seriado de um a sete dias de idade para avaliar o crescimento médio dos órgãos do sistema digestório nessa fase promoveu resultados mais confiáveis, em função do maior número de animais, do que uma análise diária dos dados obtidos, os quais foram influenciados, em grande parte, pelo efeito do animal. Em função da utilização dessa técnica foi possível correlacionar os resultados de desempenho com o desenvolvimento dos órgãos.

Nos abates aos 21 e 42 dias de idade utilizaram-se apenas duas aves por parcela o que levou a resultados contraditórios na análise de alometria dos órgãos do sistema digestório. Uma possível forma de se obterem melhores resultados nesse sentido seria a utilização de um maior número de animais por parcela, entretanto é de difícil aplicação, considerando-se que o abate e a realização das medidas é demorado e necessita de pessoal treinado.

$\mathrm{O}$ uso de ingredientes de melhor qualidade na primeira semana de idade das aves, sendo esses facilmente digeridos, contribuiu para um melhor desempenho. Porém, os melhores resultados encontrados para peso vivo e consumo de ração na primeira semana pela utilização dos carboidratos glicose, sacarose, amido de milho e amido de mandioca não se perpetuou até aos 42 dias de idade; o contrário ocorreu com os resultados de conversão alimentar que não haviam sido diferentes na fase pré-inicial e demonstrou-se diferente na fase de 21 a 42.

O fato de não se ter encontrado melhores resultados na fase de 21 a 42 dias de idade das aves para os tratamentos que utilizaram glicose, sacarose e os amidos de milho e mandioca pode ser devido ao pequeno número de animais nessa fase, apenas cinco por parcela. No entanto, experimentos realizados em baterias não permitem um número maior de aves nessa fase. 
Sendo necessário um maior número de experimentos antes de se chegar a uma conclusão para a fase de 21 a 42 dias de idade das aves. 


\section{CONCLUSÕES}

Conclui-se que o uso dos carboidratos: glicose, sacarose, amido de milho e amido de mandioca foi benéfico para o desempenho das aves na fase de um a sete dias de idade. O melhor desempenho das aves nesses tratamentos se deu, em parte, devido à melhora da capacidade do sistema digestório, especialmente do peso relativo do intestino delgado. Entretanto, o efeito observado até os sete dias de idade das aves não foi mantido nas fases posteriores. 


\section{REFERÊNCIAS BIBLIOGRÁFICAS}

AKIBA, Y.; MURAKAMI, H. Partioning of energy and protein during early growth of broiler chicks and contribution of vitteline residues. In: WORLD POULTRY SCIENCE CONFERENCE, Antalia, Turkey, 1995. Proceedings. Antalia: WPSS, 1995. p.46-52.

BARANYIOVÁ, E.; HOLMAN, J. Morphological changes in the intestinal wall in fed and fasted chickens in the first week after hatching. Acta Veterinaria, v.45, p.151-158, 1976.

CHAMBLEE, T. N.; BRAKE, J. D.; SCHULTZ, C.D.; THAXTON, J. P. Yolk sac absortion and initiation of growth in broilers. Poultry Science, v. 71, p.18111816, 1992.

CORLESS, A. B.; SELL, J. L. The effects of delayed access to feed and water on the physical and functional development of the digestive system of young turkeys. Poultry Science, v. 78, p.1158-1169, 1999.

DIBNER, J. Nutritional requirements of young poultry. In: ARKANSAS NUTRITON CONFERENCE, Fayetteville, 1996. Proceedings, Fayetteville, Arkansas: ARKANSAS POULTRY FEDERATION. 1996. p.15-27.

DIBNER, J.; PIERSON, E.M. Desenvolvimiento precoces do tubo digestivo e implicaciones para aves recen nacidas. In: SIMPOSIO DE AVANCES TECNOLÓGICOS. Cancún, 1997. Memorias, Cancún: Novus International. 1997. p.69-80. 
GUYTON, A. C. Tratado de fisiologia médica. 8. ed. Rio de Janeiro: Guanabara Koogan, 1992. 864p.

HARGIS, P. H.; CREGER, C. R. Effects of varying dietary protein and energy levels on growth rate and body fat of broilers. Poultry Science, v. 59, p.1499$1504,1980$.

JIN, S. H.; CORLESS, A.; SELL, J. L. Digestive system development in posthatch poultry. World's Poultry Science Journal, v. 54, p.335-345, 1998.

KRABBE, E.L. Níveis de sódio , tamanho de partícula da dieta e peso do pinto à eclosão e o desempenho na fase pré-inicial. Porto Alegre, 2000. p.146. Tese (Doutorado) - Universidade Federal do Rio Grande do Sul.

LILBURN, M. S. Practical aspects of early nutrition for poultry. Journal Applied. Poultry Research, v. 7, p. 420-424, 1998.

LONGO, F. A.; MENTEN, J. F. M. M.; PEDROSO, A. A.; RACANICCI, A. M. C.; FIGUEIREDO, A. N.; GAIOTTO, J. B.; SORBARA, J. O. B. Energia metabolizável de carboidratos para frangos de corte na fase pré-inicial. Revista Brasileira de Ciência Avícola, v.4, suplemento, 4. p.44, 2002.

MENTEN, J. F. M.; LONGO, F. A.; PEDROSO, A. A.; FIGUEIREDO, A. N.; RACANICCI, A. M. C.; SORBARA, J. O. B.; GAIOTTO, J. B. Valores de energia metabolizavel de milho e farelo de soja para frangos de corte na fase pré-inicial. In: (Compact Disc) REUNIÃO ANUAL DA SOCIEDADE BRASILEIRA DE ZOOTECNIA, 39, Recife, 2002. Anais. Recife: SBZ, 2002.

MICHAEL, E.; HODGES, R. D. Histochemical changes in the fowl small intestine associated with enhanced absorption after feed restriction. Histochemie, v.36, p.39-49, 1973.

MORAN JUNIOR, E. T. Effects of egg weight, glucose administration at hatch, and delayed access to feed and water on the poult at 2 weeks of age. Poultry Science, v. 69, p.1718-1723, 1990. 
MORAN JUNIOR, E. T. Starch digestion in fowl. Poultry Science, v. 61, p.1257-1267, 1982.

MORAN JUNIOR, E. T. Subcutaneous glucose is more advantageous in establishing the posthatch poult than oral administration. Poultry Science, v. 67, p.493-501, 1988.

MURAKAMI, H.; AKIBA, Y.; HORIGUCHI, M. Growth and utilization of nutrients in newly-hatched chick with or without removal of residual yolk. Growth, Development And Aging, v. 56, p.75-84, 1992.

NIR , I.; LEVANON, M. Effect of posthatch holding time on performance and on residual yolk and liver composition. Poultry Science, v. 72, p.1994-1997, 1993.

NITSAN, Z.; TURRO-VINCENT, I.; LIU, G.; DUNNINGTON, E. A.; SIEGEL, P. B. Intubation of weight-select chicks with soybean oil or residual yolk: effect early growth and development. Poultry Science, v. 74, p.925-936, 1995.

NOY, Y.; SKLAN, D. Digestion and absorption in the young chick. Poultry Science, v. 74, p.366-373, 1995.

NOY, Y.; SKLAN, D. Posthatch development in poultry. Journal Applied. Poultry Research, v. 6, p.344-354, 1997.

NOY, Y.; SKLAN, D. Metabolic response to early nutrition. Journal Applied Poultry Research, v. 7, p.437-451, 1998.

NOY, Y.; UNI, Z.; SKLAN, D. Routes of yolk utilization in the newly-hatched chick. British Poultry Science, v. 37, p.987-996, 1996.

NRC, NATIONAL RESEARCH COUNCIL. Nutrients Requirements of Poultry, Washington D.C.: National Academy Press, 155p. 1994. 
PENZ JUNIOR, A. M.; VIEIRA, S. L. Nutrição na primeira semana. In: CONFERÊNCIA APINCO'98 DE CIÊNCIA E TECNOLOGIA AVÍCOLA SIMPÓSIO INTERNACIONAL SOBRE MANEJO DE PINTOS DE CORTE NA PRIMEIRA SEMANA, Campinas, 1998. Anais. Campinas: FACTA, p. 121139, 1998.

PENZ JUNIOR, A. M.; VIEIRA, S. L. Broiler pre-starter feed formulation. In: ANNUAL NUTRITION CONFERENCE, Fayetteville, 2000. Proceedings, Fayetteville, Arkansas: THE POULTRY FEDERATION, 2000.

ROSENSWEIG, N. S.; HERMAN, R. H. Dose response of jejunal disaccharidase activity to varying carbohydrate diets in man. American Journal of Clinical Nutrition, v. 21, p. 536, 1968.

ROSTAGNO, H. S. Fisiologia da digestão e absorção das aves. Campinas: Fundação APINCO de ciência e tecnologia avícolas, 1994. p. 43-58: Carboidratos.

ROSTAGNO, H. S.; ALBINO, L. F. T.; DONZELE, J. L.; GOMES, P. C.; FERREIRA, A. S.; OLIVEIRA, R. F.; LOPES, D. C. Tabelas brasileiras para aves e suínos : composição de alimentos e exigências nutricionais. Viçosa: Horacio Santiago Rostagno (Ed.), UFV, Departamento de Zootecnia, 2000. $141 \mathrm{p}$.

SAS INSTITUTE. SAS user's guide: version 6.11. Cary, 1996. 956p.

SELL, J.L.; KOLODOVSKI, O.; REID, B.L. Intestinal disaccharidase of young turkeys: temporal development and influence of diet composition. Poultry Science, v.68, p. 265-277, 1989.

SIDDONS, R. C. Effect of diet on disaccharidase activity in the chick. British Journal Nutrition., v. 27, p. 343-352, 1972.

SULISTIYANTO, B.; AKIBA, Y.; SATOH, K. Energy utilisation of carbohydrates, fat and protein sources in newly hatched broiler chicks. British Poultry Science, v. 40, p. 653-659, 1999. 
TARVID, I. L. The development of protein digestion in poultry. Poultry and Avian Biology Review, v. 6, p. 35-54, 1995.

TURNER, K.; APPLEGATE, T. J.; LILBURN, M. S. Effects of feeding high carbohydrate and fat diets. 1. Growth and metabolic status of the posthatch poult following immediate or delayed access to feed. Poultry Science, v. 78, p.1573-1580, 1999.

UNI, Z.; GANOT, S.; SKLAN, D. Posthatch development of mucosal function in the broiler small intestine. Poultry Science, v. 77, p.75-82, 1998.

VIEIRA, S. L. Carboidratos: digestão e absorção. In: MACARI, M., FURLAN, R. L., GONZÁLES, E. (Ed.). Fisiologia aviária aplicada a frangos de corte. Jaboticabal:Funep/Unesp, 2002. cap. 9, p.125-133.

VIEIRA, S. L.; MORAN JUNIOR, E. T. Effects of egg of origin and chick posthatch nutrition on broiler live performance and meat yields. World's Poultry Science Journal, v. 55, p. 125-142, 1999a.

VIEIRA, S. L.; MORAN JUNIOR, E. T. Starter vs. Corn and supplemental calcium propionate in initial broiler feeding. Journal Applied Poultry Research, v. 8, p. 255-262, 1999b.

WALDROUP, P.W.; HILIARD, C. M.; CRIGG, J. E.; HARRIS, G. C. The effectiveness of drinking solutions given to young turkey poults in drinking water or by oral and parenteral dosage. Poultry Science, v. 53, p. 10561060, 1974. 


\section{APÊNDICES}


APÊNDICE 1 - Consumo de ração $(\mathrm{g})$ de 1 a 7,7 a 21 e 21 a 42 dias de idade de frangos de corte.

\begin{tabular}{cccc}
\hline Tratamentos & 1 a 7 dias & 7 a 21 dias & 21 a 42 dias \\
\hline Testemunha 1 & 138,42 & 846,38 & 3060,20 \\
Testemunha 2 & 142,32 & 881,42 & 2883,00 \\
Testemunha 3 & 136,33 & 897,00 & 2774,80 \\
Testemunha 4 & 147,49 & 885,73 & 2819,60 \\
Média & 141,14 & 877,63 & 2884,40 \\
Glicose 1 & 164,15 & 893,29 & 2861,80 \\
Glicose 2 & 164,24 & 924,55 & 3110,20 \\
Glicose 3 & 148,25 & 891,97 & 2920,00 \\
Glicose 4 & 153,15 & 910,83 & 3003,80 \\
Média & 157,45 & 905,16 & 2973,95 \\
Sacarose 1 & 145,69 & 846,83 & 2725,20 \\
Sacarose 2 & 156,35 & 972,73 & 3027,60 \\
Sacarose 3 & 155,54 & 897,00 & 2999,20 \\
Sacarose 4 & 139,83 & 858,93 & 2907,80 \\
Média & 149,35 & 893,87 & 2914,95 \\
Amido de Milho 1 & 144,77 & 832,00 & 2941,60 \\
Amido de Milho 2 & 143,14 & 922,73 & 3002,20 \\
Amido de Milho 3 & 144,00 & 882,14 & 2986,40 \\
Amido de Milho 4 & 136,55 & 841,67 & 2839,40 \\
Média & 142,11 & 869,63 & 2942,40 \\
Amido de Mandioca 1 & 147,64 & 994,55 & 2917,60 \\
Amido de Mandioca 2 & 151,76 & 910,91 & 2736,40 \\
Amido de Mandioca 3 & 146,56 & 934,55 & 2960,60 \\
Amido de Mandioca 4 & 142,77 & 898,26 & 2902,00 \\
Média & 147,18 & 934,56 & 2879,15 \\
Lactose 1 & 144,16 & 916,55 & 2889,60 \\
Lactose 2 & 144,66 & 868,18 & 2723,20 \\
Lactose 3 & 136,84 & 924,55 & 3046,80 \\
Lactose 4 & 144,51 & 839,54 & 3064,20 \\
Média & 142,54 & 887,20 & 2930,95 \\
\hline & & & \\
\hline
\end{tabular}


APÊNDICE 2 - Ganho de peso (g) de 1 a 7,7 a 21 e 21 a 42 dias de idade de frangos de corte.

\begin{tabular}{cccc}
\hline Tratamentos & 1 a 7 dias & 7 a 21 dias & 21 a 42 dias \\
\hline Testemunha 1 & 124,69 & 604,70 & 1702,80 \\
Testemunha 2 & 130,27 & 611,12 & 1572,00 \\
Testemunha 3 & 122,37 & 626,17 & 1529,20 \\
Testemunha 4 & 131,90 & 603,33 & 1582,40 \\
Média & 127,31 & 611,33 & 1596,60 \\
Glicose 1 & 154,00 & 622,23 & 1562,60 \\
Glicose 2 & 148,12 & 638,76 & 1664,00 \\
Glicose 3 & 128,54 & 628,31 & 1625,20 \\
Glicose 4 & 136,32 & 617,05 & 1656,20 \\
Média & 141,74 & 626,59 & 1627,00 \\
Sacarose 1 & 127,08 & 570,31 & 1405,00 \\
Sacarose 2 & 145,54 & 657,14 & 1613,80 \\
Sacarose 3 & 136,85 & 598,19 & 1606,00 \\
Sacarose 4 & 129,42 & 591,21 & 1514,60 \\
Média & 134,72 & 604,21 & 1534,85 \\
Amido de Milho 1 & 132,92 & 618,79 & 1611,00 \\
Amido de Milho 2 & 126,27 & 640,47 & 1643,60 \\
Amido de Milho 3 & 138,54 & 650,94 & 1598,60 \\
Amido de Milho 4 & 132,60 & 547,19 & 1564,40 \\
Média & 132,58 & 614,35 & 1604,40 \\
Amido de Mandioca 1 & 138,27 & 639,62 & 1578,00 \\
Amido de Mandioca 2 & 135,08 & 630,99 & 1512,80 \\
Amido de Mandioca 3 & 136,65 & 658,64 & 1548,60 \\
Amido de Mandioca 4 & 133,54 & 623,95 & 1575,60 \\
Média & 135,88 & 638,30 & 1553,75 \\
Lactose 1 & 129,31 & 643,35 & 1529,00 \\
Lactose 2 & 130,19 & 602,37 & 1519,40 \\
Lactose 3 & 130,38 & 649,03 & 1640,00 \\
Lactose 4 & 136,19 & 554,39 & 1691,60 \\
Média & 131,52 & 612,29 & 1595,00 \\
\hline
\end{tabular}


APÊNDICE 3 - Conversão alimentar de 1 a 7,7 a 21 e 21 a 42 dias de idade de frangos de corte.

\begin{tabular}{cccc}
\hline Tratamentos & 1 a 7 dias & 7 a 21 dias & 21 a 42 dias \\
\hline Testemunha 1 & 1,11 & 1,34 & 1,80 \\
Testemunha 2 & 1,09 & 1,39 & 1,83 \\
Testemunha 3 & 1,11 & 1,49 & 1,81 \\
Testemunha 4 & 1,12 & 1,43 & 1,78 \\
Média & 1,11 & 1,41 & 1,80 \\
Glicose 1 & 1,07 & 1,45 & 1,83 \\
Glicose 2 & 1,11 & 1,47 & 1,87 \\
Glicose 3 & 1,15 & 1,43 & 1,80 \\
Glicose 4 & 1,12 & 1,47 & 1,81 \\
Média & 1,11 & 1,45 & 1,83 \\
Sacarose 1 & 1,15 & 1,44 & 1,94 \\
Sacarose 2 & 1,07 & 1,46 & 1,88 \\
Sacarose 3 & 1,14 & 1,40 & 1,87 \\
Sacarose 4 & 1,08 & 1,41 & 1,92 \\
Média & 1,11 & 1,43 & 1,90 \\
Amido de Milho 1 & 1,09 & 1,31 & 1,83 \\
Amido de Milho 2 & 1,13 & 1,43 & 1,83 \\
Amido de Milho 3 & 1,04 & 1,35 & 1,87 \\
Amido de Milho 4 & 1,03 & 1,50 & 1,82 \\
Média & 1,07 & 1,40 & 1,84 \\
Amido de Mandioca 1 & 1,07 & 1,52 & 1,85 \\
Amido de Mandioca 2 & 1,12 & 1,47 & 1,81 \\
Amido de Mandioca 3 & 1,07 & 1,45 & 1,91 \\
Amido de Mandioca 4 & 1,07 & 1,45 & 1,84 \\
Média & 1,08 & 1,47 & 1,85 \\
Lactose 1 & 1,11 & 1,44 & 1,89 \\
Lactose 2 & 1,11 & 1,38 & 1,79 \\
Lactose 3 & 1,05 & 1,44 & 1,81 \\
Lactose 4 & 1,06 & 1,44 & 1,84 \\
Média & 1,08 & 1,42 & \\
\hline
\end{tabular}


APÊNDICE 4 - Peso vivo (g) aos 7, 21 e 42 dias de idade de frangos de corte.

\begin{tabular}{cccc}
\hline Tratamentos & 7 dias & 21 dias & 42 dias \\
\hline Testemunha 1 & 173,08 & 777,78 & 2508 \\
Testemunha 2 & 177,77 & 788,89 & 2386 \\
Testemunha 3 & 170,83 & 797,00 & 2302 \\
Testemunha 4 & 177,79 & 781,11 & 2380 \\
Média & 174,87 & 786,19 & 2394,00 \\
Glicose 1 & 202,77 & 825,00 & 2382 \\
Glicose 2 & 196,69 & 835,45 & 2488 \\
Glicose 3 & 175,69 & 804,00 & 2426 \\
Glicose 4 & 183,79 & 800,83 & 2458 \\
Média & 189,73 & 816,32 & 2438,50 \\
Sacarose 1 & 174,69 & 745,00 & 2166 \\
Sacarose 2 & 193,77 & 850,91 & 2476 \\
Sacarose 3 & 184,31 & 782,50 & 2430 \\
Sacarose 4 & 177,54 & 768,75 & 2302 \\
Média & 182,58 & 786,79 & 2343,50 \\
Amido de Milho 1 & 182,46 & 801,25 & 2428 \\
Amido de Milho 2 & 174,08 & 814,55 & 2462 \\
Amido de Milho 3 & 185,31 & 836,25 & 2438 \\
Amido de Milho 4 & 178,64 & 725,83 & 2306 \\
Média & 180,12 & 794,47 & 2408,50 \\
Amido de Mandioca 1 & 184,92 & 824,55 & 2418 \\
Amido de Mandioca 2 & 184,46 & 815,45 & 2316 \\
Amido de Mandioca 3 & 185,00 & 843,64 & 2380 \\
Amido de Mandioca 4 & 181,50 & 805,45 & 2378 \\
Média & 183,97 & 822,27 & 2373,00 \\
Lactose 1 & 178,08 & 821,43 & 2344 \\
Lactose 2 & 178,54 & 780,91 & 2328 \\
Lactose 3 & 179,15 & 828,18 & 2462 \\
Lactose 4 & 183,38 & 737,78 & 2460 \\
Média & 179,79 & 792,07 & 2398,50 \\
\hline
\end{tabular}


APÊNDICE 5 - Viabilidade criatória (\%) de 1 a 7,7 a 21 e 21 a 42 dias de idade frangos de corte.

\begin{tabular}{cccc}
\hline Tratamentos & 1 a 7 dias & 7 a 21 dias & 21 a 42 dias \\
\hline Testemunha 1 & 92,9 & 81,8 & 100,0 \\
Testemunha 2 & 92,9 & 81,8 & 100,0 \\
Testemunha 3 & 85,7 & 100,0 & 100,0 \\
Testemunha 4 & 100,0 & 75,0 & 100,0 \\
Média & 92,86 & 84,7 & 100,0 \\
Glicose 1 & 92,9 & 72,7 & 100,0 \\
Glicose 2 & 92,9 & 100,0 & 100,0 \\
Glicose 3 & 92,9 & 90,9 & 100,0 \\
Glicose 4 & 100,0 & 100,0 & 100,0 \\
Média & 94,6 & 90,9 & 100,0 \\
Sacarose 1 & 92,9 & 90,9 & 100,0 \\
Sacarose 2 & 92,9 & 100,0 & 100,0 \\
Sacarose 3 & 92,9 & 72,7 & 100,0 \\
Sacarose 4 & 92,9 & 72,7 & 100,0 \\
Média & 92,9 & 84,1 & 100,0 \\
Amido de Milho 1 & 92,9 & 72,7 & 100,0 \\
Amido de Milho 2 & 92,9 & 100,0 & 100,0 \\
Amido de Milho 3 & 92,9 & 72,7 & 100,0 \\
Amido de Milho 4 & 100,0 & 100,0 & 100,0 \\
Média & 94,6 & 86,4 & 100,0 \\
Amido de Mandioca 1 & 92,9 & 100,0 & 100,0 \\
Amido de Mandioca 2 & 92,9 & 100,0 & 100,0 \\
Amido de Mandioca 3 & 92,9 & 100,0 & 100,0 \\
Amido de Mandioca 4 & 100,0 & 91,7 & 100,0 \\
Média & 94,6 & 97,9 & 100,0 \\
Lactose 1 & 92,9 & 63,6 & 100,0 \\
Lactose 2 & 92,9 & 100,0 & 100,0 \\
Lactose 3 & 92,9 & 100,0 & 100,0 \\
Lactose 4 & 92,9 & 81,8 & 100,0 \\
Média & 92,9 & 86,4 & 100,0 \\
\hline
\end{tabular}


APÊNDICE 6 - Média de duas aves por parcela do peso relativo do saco vitelino (\% do peso vivo) de 1 a 7 dias de idade.

\begin{tabular}{cccccccc}
\hline & \multicolumn{7}{c}{ Idade (dias) } \\
Tratamentos & Dia 1 & Dia 2 & Dia 3 & Dia 4 & Dia 5 & Dia 6 & Dia 7 \\
\hline Testemunha 1 & 8,30 & 2,28 & 1,74 & 0,68 & 0,24 & 0,47 & 0,26 \\
Testemunha 2 & 5,86 & 2,41 & 0,89 & 0,82 & 0,37 & 0,24 & 0,05 \\
Testemunha 3 & 4,04 & 2,43 & 1,70 & 1,43 & 0,29 & 0,25 & 0,44 \\
Testemunha 4 & 4,71 & 2,43 & 0,90 & 0,61 & 0,48 & 0,29 & 0,10 \\
Média & 5,73 & 2,39 & 1,31 & 0,88 & 0,34 & 0,31 & 0,21 \\
Glicose 1 & 5,74 & 1,67 & 0,64 & 0,74 & 0,36 & 0,22 & 0,16 \\
Glicose 2 & 7,55 & 1,81 & 1,18 & 0,47 & 0,31 & 0,18 & 0,18 \\
Glicose 3 & 6,21 & 1,46 & 1,44 & 0,46 & 0,27 & 0,22 & 0,07 \\
Glicose 4 & 5,73 & 2,17 & 1,52 & 0,42 & 0,44 & 0,14 & 0,18 \\
Média & 6,31 & 1,78 & 1,20 & 0,52 & 0,34 & 0,19 & 0,15 \\
Sacarose 1 & 5,10 & 3,61 & 1,63 & 2,58 & 0,39 & 0,27 & 0,37 \\
Sacarose 2 & 4,45 & 3,98 & 2,58 & 0,45 & 0,36 & 0,26 & 0,12 \\
Sacarose 3 & 6,07 & 4,13 & 1,57 & 0,47 & 0,38 & 0,11 & 0,31 \\
Sacarose 4 & 6,61 & 2,13 & 0,91 & 1,06 & 0,33 & 0,14 & 0,35 \\
Média & 5,56 & 3,46 & 1,67 & 1,14 & 0,36 & 0,20 & 0,29 \\
Amido de Milho 1 & 8,94 & 3,68 & 1,69 & 0,53 & 0,17 & 0,34 & 0,16 \\
Amido de Milho 2 & 7,47 & 2,92 & 2,10 & 0,47 & 0,21 & 0,07 & 0,14 \\
Amido de Milho 3 & 5,58 & 1,76 & 1,38 & 0,55 & 0,46 & 0,10 & 0,14 \\
Amido de Milho 4 & 5,54 & 4,11 & 0,99 & 0,39 & 0,36 & 0,34 & 0,20 \\
Média & 6,88 & 3,12 & 1,54 & 0,48 & 0,30 & 0,21 & 0,16 \\
Amido de Mandioca 1 & 4,18 & 4,75 & 0,87 & 0,88 & 0,18 & 0,18 & 0,10 \\
Amido de Mandioca 2 & 4,76 & 1,51 & 1,34 & 1,80 & 1,05 & 0,49 & 0,22 \\
Amido de Mandioca 3 & 8,26 & 2,03 & 1,38 & 0,45 & 0,22 & 0,17 & 0,08 \\
Amido de Mandioca 4 & 5,30 & 1,36 & 1,45 & 0,43 & 0,89 & 0,17 & 0,30 \\
Média & 5,62 & 2,41 & 1,26 & 0,89 & 0,58 & 0,25 & 0,18 \\
Lactose 1 & 4,20 & 1,88 & 0,58 & 1,35 & 0,39 & 0,55 & 0,28 \\
Lactose 2 & 3,57 & 2,37 & 1,82 & 1,32 & 0,35 & 0,10 & 0,15 \\
Lactose 3 & 6,19 & 2,45 & 1,11 & 0,70 & 0,58 & 0,08 & 0,13 \\
Lactose 4 & 5,34 & 3,32 & 0,79 & 0,71 & 0,52 & 0,35 & 0,08 \\
Média & 4,82 & 2,51 & 1,08 & 1,02 & 0,46 & 0,27 & 0,16 \\
\hline & & & & & & &
\end{tabular}


APÊNDICE 7 - Média de duas aves por parcela do peso relativo do proventrículo (\% do peso vivo) de 1 a 7,21 e 42 dias de idade.

\begin{tabular}{|c|c|c|c|c|c|c|c|c|c|}
\hline \multirow{2}{*}{ Tratamentos } & \multicolumn{9}{|c|}{ Idade (dias) } \\
\hline & 1 & 2 & 3 & 4 & 5 & 6 & 7 & 21 & 42 \\
\hline Testemunha 1 & 1,53 & 1,35 & 1,40 & 1,56 & 1,19 & 1,20 & 1,00 & 0,46 & 0,34 \\
\hline Testemunha 2 & 1,57 & 1,55 & 1,45 & 1,38 & 1,24 & 1,32 & 1,12 & 0,47 & 0,37 \\
\hline Testemunha 3 & 1,21 & 1,20 & 1,24 & 1,53 & 1,24 & 1,15 & 1,07 & 0,47 & 0,31 \\
\hline Testemunha 4 & 1,05 & 1,15 & 1,32 & 1,63 & 1,22 & 1,36 & 0,99 & 0,54 & 0,31 \\
\hline Média & 1,34 & 1,31 & 1,35 & 1,53 & 1,22 & 1,26 & 1,04 & 0,48 & 0,33 \\
\hline Glicose 1 & 0,92 & 1,32 & 1,17 & 1,38 & 1,30 & 1,68 & 1,57 & 0,48 & 0,40 \\
\hline Glicose 2 & 1,09 & 1,39 & 0,83 & 1,43 & 1,88 & 1,43 & 1,13 & 0,46 & 0,37 \\
\hline Glicose 3 & 1,21 & 1,20 & 1,38 & 1,15 & 1,14 & 1,35 & 1,17 & 0,47 & 0,29 \\
\hline Glicose 4 & 1,17 & 1,20 & 1,41 & 1,41 & 1,62 & 1,33 & 1,21 & 0,47 & 0,26 \\
\hline Média & 1,10 & 1,28 & 1,20 & 1,34 & 1,49 & 1,45 & 1,27 & 0,47 & 0,33 \\
\hline Sacarose 1 & 1,01 & 1,31 & 1,55 & 1,26 & 1,31 & 1,18 & 1,02 & 0,61 & 0,30 \\
\hline Saca & 1,27 & 1,56 & 1,36 & 1,30 & 1,31 & 0,99 & 1,04 & 0,45 & 0,37 \\
\hline Sacarose 3 & 1,16 & 1,20 & 1,31 & 1,21 & 1,31 & 1,21 & 1,01 & 0,47 & 0,31 \\
\hline Sacal & 1,44 & 1,29 & 1,34 & 1,54 & 1,30 & 1,24 & 1,36 & 0,47 & 0,35 \\
\hline Média & 1,22 & 1,34 & 1,39 & 1,33 & 1,31 & 1,15 & 1,11 & 0,50 & 0,33 \\
\hline Amido de Milho 1 & 0,83 & 1,46 & 1,47 & 1,54 & 1,40 & 1,22 & 1,08 & 0,44 & 0,42 \\
\hline Amido de Milho 2 & 1,18 & 1,27 & 1,33 & 1,47 & 1,11 & 1,05 & 1,24 & 0,45 & 0,37 \\
\hline Amido de Milho 3 & 1,15 & 1,19 & 1,41 & 1,55 & 1,23 & 1,05 & 0,93 & 0,46 & 0,42 \\
\hline Amido & 1,05 & 1,08 & 1,43 & 1,45 & 1,38 & 1,29 & 0,99 & 0,50 & 0,32 \\
\hline Média & 1,05 & 1,25 & 1,41 & 1,50 & 1,28 & 1,15 & 1,06 & 0,46 & 0,38 \\
\hline Amido de Mandioca 1 & 1,40 & 1,31 & 1,44 & 1,35 & 1,42 & 1,14 & 1,17 & 0,52 & 0,32 \\
\hline Amido de Mandioca 2 & 1,60 & 1,07 & 1,57 & 1,34 & 1,33 & 1,12 & 1,09 & 0,54 & 0,33 \\
\hline Amido de Mandioca 3 & 1,22 & 1,26 & 1,36 & 1,47 & 1,32 & 1,09 & 1,21 & 0,48 & 0,35 \\
\hline Amido de Mandioca 4 & 1,10 & 1,29 & 1,32 & 1,34 & 1,56 & 1,18 & 0,92 & 0,46 & 0,29 \\
\hline Média & 1,33 & 1,23 & 1,42 & 1,38 & 1,41 & 1,13 & 1,10 & 0,50 & 0,32 \\
\hline Lactose 1 & 1,16 & 1,23 & 1,37 & 1,55 & 1,32 & 1,09 & 1,33 & 0,50 & 0,34 \\
\hline Lactose 2 & 1,07 & 1,24 & 1,35 & 1,26 & 1,27 & 1,15 & 1,12 & 0,43 & 0,33 \\
\hline Lactose 3 & 0,83 & 1,18 & 1,27 & 1,48 & 1,58 & 1,32 & 1,11 & 0,44 & 0,32 \\
\hline Lact & 1,01 & 1,46 & 1,45 & 1,42 & 1,31 & 1,16 & 1,35 & 0,57 & 0,39 \\
\hline Média & 1,01 & 1,28 & 1,36 & 1,43 & 1,37 & 1,18 & 1,23 & 0,49 & 0,34 \\
\hline
\end{tabular}


APÊNDICE 8 - Média de duas aves por parcela do peso relativo da moela (\% do peso vivo) de 1 a 7,21 e 42 dias de idade.

\begin{tabular}{|c|c|c|c|c|c|c|c|c|c|}
\hline \multirow{2}{*}{ Tratamentos } & \multicolumn{9}{|c|}{ Idade (dias) } \\
\hline & 1 & 2 & 3 & 4 & 5 & 6 & 7 & 21 & 42 \\
\hline Testemunha 1 & 4,66 & 6,07 & 6,28 & 5,37 & 4,25 & 4,53 & 4,11 & 2,61 & 1,44 \\
\hline Testemunha 2 & 5,10 & 5,76 & 5,97 & 5,42 & 4,96 & 5,19 & 4,67 & 2,37 & 1,62 \\
\hline Testemunha 3 & 5,76 & 6,38 & 5,79 & 5,41 & 5,31 & 4,45 & 4,88 & 2,25 & 1,53 \\
\hline Testemunha 4 & 5,42 & 5,55 & 5,78 & 5,02 & 4,74 & 4,27 & 3,60 & 2,39 & 1,12 \\
\hline Média & 5,24 & 5,94 & 5,96 & 5,30 & 4,81 & 4,61 & 4,31 & 2,41 & 1,43 \\
\hline Glicose 1 & 5,25 & 5,80 & 5,03 & 4,54 & 4,60 & 4,05 & 4,04 & 2,49 & 1,71 \\
\hline Glicose 2 & 5,68 & 5,08 & 5,23 & 5,01 & 4,27 & 4,27 & 3,92 & 1,99 & 1,74 \\
\hline Glicose 3 & 5,52 & 5,32 & 5,17 & 4,60 & 4,97 & 4,62 & 4,26 & 2,21 & 1,53 \\
\hline Glicose 4 & 5,29 & 5,28 & 5,67 & 5,26 & 4,26 & 4,13 & 4,26 & 2,25 & 1,22 \\
\hline Média & 5,43 & 5,37 & 5,28 & 4,86 & 4,53 & 4,27 & 4,12 & 2,23 & 1,55 \\
\hline Sacarose 1 & 6,06 & 5,51 & 5,64 & 4,35 & 4,53 & 4,04 & 4,01 & 2,78 & 1,25 \\
\hline Sacar & 5,34 & 6,05 & 5,39 & 5,17 & 5,13 & 4,23 & 4,52 & 2,34 & 1,52 \\
\hline Sacarose 3 & 5,84 & 5,79 & 5,58 & 4,91 & 4,70 & 4,85 & 4,25 & 2,18 & 1,48 \\
\hline Sacar & 5,26 & 5,74 & 5,41 & 5,40 & 4,76 & 4,70 & 4,76 & 2,19 & 1,38 \\
\hline Média & 5,62 & 5,77 & 5,51 & 4,96 & 4,78 & 4,46 & 4,38 & 2,37 & 1,41 \\
\hline Amido de Milho 1 & 4,96 & 5,79 & 5,37 & 5,23 & 5,20 & 4,14 & 4,04 & 2,62 & 1,46 \\
\hline Amido de Milho 2 & 5,75 & 5,34 & 5,51 & 5,04 & 4,69 & 4,28 & 4,41 & 2,39 & 1,44 \\
\hline Amido de Milho 3 & 5,32 & 5,36 & 5,73 & 5,21 & 4,57 & 4,46 & 4,65 & 2,60 & 1,51 \\
\hline Amido & 5,55 & 5,57 & 5,51 & 5,06 & 5,24 & 4,53 & 3,72 & 3,02 & 1,38 \\
\hline Média & 5,39 & 5,52 & 5,53 & 5,14 & 4,92 & 4,35 & 4,21 & 2,66 & 1,45 \\
\hline Amido de Mandioca 1 & 5,79 & 5,55 & 5,71 & 5,27 & 5,26 & 4,30 & 4,20 & 2,11 & 1,25 \\
\hline Amido de Mandioca 2 & 5,18 & 5,21 & 5,60 & 5,03 & 4,08 & 4,42 & 4,04 & 2,43 & 1,46 \\
\hline Amido de Mandioca 3 & 5,82 & 5,62 & 5,71 & 5,19 & 4,54 & 4,45 & 4,17 & 2,13 & 1,34 \\
\hline Amido de Mandioca 4 & 5,44 & 5,43 & 5,32 & 4,98 & 5,24 & 4,18 & 3,97 & 2,24 & 1,15 \\
\hline Módia & 5,56 & 5,45 & 5,58 & 5,12 & 4,78 & 4,34 & 4,10 & 2,23 & 1,30 \\
\hline Lactose 1 & 5,47 & 5,51 & 5,32 & 5,20 & 4,84 & 4,88 & 4,46 & 2,37 & 1,28 \\
\hline Lactose 2 & 5,72 & 5,84 & 5,90 & 5,60 & 5,00 & 4,23 & 4,30 & 2,51 & 1,53 \\
\hline Lactose 3 & 5,32 & 5,77 & 5,35 & 5,60 & 5,42 & 4,49 & 4,56 & 2.01 & 1.40 \\
\hline Lactose 4 & 5,75 & 5,89 & 5,03 & 5,22 & 5,07 & 4,83 & 4,54 & 2,35 & 1,54 \\
\hline Média & 5,57 & 5,75 & 5,40 & 5,41 & 5,08 & 4,61 & 4,47 & 2,31 & 1,44 \\
\hline
\end{tabular}


APÊNDICE 9 - Média de duas aves por parcela do peso relativo do intestino delgado (\% do peso vivo) de 1 a 7,21 e 42 dias de idade.

\begin{tabular}{|c|c|c|c|c|c|c|c|c|c|}
\hline \multirow{2}{*}{ Tratamentos } & \multicolumn{9}{|c|}{ Idade (dias) } \\
\hline & 1 & 2 & 3 & 4 & 5 & 6 & 7 & 21 & 42 \\
\hline Testemunha 1 & 2,42 & 2,88 & 3,37 & 4,06 & 4,86 & 4,82 & 4,39 & 2,81 & 2,11 \\
\hline Testemunha 2 & 2,52 & 2,96 & 4,86 & 4,50 & 4,86 & 4,44 & 4,15 & 2,84 & 2,04 \\
\hline Testemunha 3 & 3,80 & 3,73 & 4,30 & 4,98 & 5,27 & 5,67 & 4,75 & 3,02 & 1,68 \\
\hline Testemunha 4 & 3,11 & 3,62 & 5,18 & 4,30 & 4,83 & 4,53 & 4,85 & 3,09 & 2,10 \\
\hline Média & 2,96 & 3,30 & 4,43 & 4,46 & 4,95 & 4,87 & 4,54 & 2,94 & 1,98 \\
\hline Glicose 1 & 3,33 & 3,88 & 4,22 & 4,12 & 4,23 & 4,87 & 4,24 & 2,99 & 2,28 \\
\hline Glicose 2 & 3,08 & 2,90 & 3,77 & 4,08 & 4,53 & 4,89 & 4,96 & 2,82 & 1,99 \\
\hline Glicose 3 & 2,60 & 3,58 & 4,35 & 4,46 & 4,50 & 4,70 & 5,50 & 2,76 & 2,02 \\
\hline Glicose 4 & 3,41 & 3,51 & 4,32 & 4,14 & 4,82 & 5,00 & 4,19 & 3,08 & 2,06 \\
\hline Média & 3,11 & 3,47 & 4,16 & 4,20 & 4,52 & 4,86 & 4,72 & 2,91 & 2,09 \\
\hline Sacarc & 3,31 & 2,79 & 4,82 & 3,95 & 5,90 & 5,44 & 4,57 & 3,30 & 2,33 \\
\hline Sace & 3,79 & 3,89 & 4,04 & 4,52 & 4,67 & 5,93 & 4,67 & 2,87 & 2,24 \\
\hline Sacarose 3 & 5,12 & 3,94 & 4,79 & 4,72 & 4,49 & 4,41 & 4,73 & 2,76 & 1,94 \\
\hline Sacarose 4 & 2,97 & 4,12 & 5,03 & 4,62 & 5,34 & 7,21 & 5,28 & 3,02 & 2,15 \\
\hline Média & 3,80 & 3,69 & 4,67 & 4,45 & 5,10 & 5,75 & 4,81 & 2,99 & 2,17 \\
\hline Amido de Milho 1 & 2,82 & 4,16 & 4,98 & 5,38 & 4,36 & 4,86 & 3,80 & 2,54 & 2,00 \\
\hline Amido de Milho 2 & 3,62 & 4,24 & 5,51 & 5,49 & 5,50 & 5,49 & 5,95 & 3,02 & 1,84 \\
\hline Amido de Milho 3 & 2,83 & 3,14 & 3,41 & 4,06 & 4,58 & 5,03 & 4,28 & 2,85 & 2,12 \\
\hline Amido de Milho 4 & 3,36 & 4,27 & 4,18 & 5,53 & 5,87 & 4,69 & 4,41 & 2,87 & 1,99 \\
\hline Média & 3,16 & 3,95 & 4,52 & 5,12 & 5,08 & 5,01 & 4,61 & 2,82 & 1,98 \\
\hline de Mandioca 1 & 3,51 & 3,92 & 4,98 & 4,41 & 4,77 & - & 4,56 & 3,24 & 2,05 \\
\hline Amido de Mandioca 2 & 2,78 & 4,13 & 4,32 & 4,86 & 4,78 & 5,53 & 4,40 & 3,10 & 1,90 \\
\hline Amido de Mandioca 3 & 3,73 & 4,24 & 4,04 & 4,86 & 4,98 & 4,48 & 4,46 & 2,91 & 2,07 \\
\hline Amido de Mandioca 4 & 2,27 & 3,25 & 4,97 & 3,93 & 4,33 & 5,36 & 4,68 & 2,67 & 1,91 \\
\hline Módia & 3,08 & 3,88 & 4,58 & 4,51 & 4,72 & 5,12 & 4,52 & 2,98 & 1,98 \\
\hline Lactose 1 & 2,56 & 3,89 & 5,16 & 4,91 & 6,32 & 6,40 & 5,50 & 3,17 & 2,57 \\
\hline Lactose 2 & 3,05 & 3,52 & 5,21 & 4,87 & 4,65 & 5,49 & 5,19 & 2,89 & 2,04 \\
\hline Lactose 3 & 2,85 & 3,80 & 4,64 & 4,49 & 5,17 & 5,26 & 5,01 & 2,99 & 2,25 \\
\hline Lactc & 1,95 & 4,14 & 4,99 & 4,93 & 4,83 & 5,25 & 5,76 & 2,78 & 2,49 \\
\hline Média & 2,61 & 3,84 & 5,00 & 4,80 & 5,24 & 5,60 & 5,36 & 2,96 & 2,34 \\
\hline
\end{tabular}


APÊNDICE 10 - Média de duas aves por parcela do comprimento do intestino delgado de 1 a 7, 21 e 42 dias de idade.

\begin{tabular}{cccccccccc}
\hline Tratamentos & 1 & 2 & 3 & 4 & 5 & 6 & 7 & 21 & 42 \\
\hline Testemunha 1 & 53 & 60 & 64 & 82 & 98 & 84 & 88 & 122 & 155 \\
Testemunha 2 & 53 & 63 & 71 & 78 & 86 & 80 & 102 & 125 & 171 \\
Testemunha 3 & 50 & 51 & 70 & 80 & 86 & 99 & 95 & 139 & 135 \\
Testemunha 4 & 57 & 60 & 73 & 81 & 89 & 93 & 103 & 120 & 157 \\
Média & 53 & 59 & 69 & 80 & 90 & 89 & 97 & 127 & 154 \\
Glicose 1 & 54 & 62 & 74 & 75 & 90 & 94 & 99 & 129 & 142 \\
Glicose 2 & 46 & 58 & 69 & 73 & 89 & 94 & 95 & 129 & 140 \\
Glicose 3 & 50 & 63 & 67 & 79 & 82 & 92 & 103 & 133 & 145 \\
Glicose 4 & 57 & 61 & 74 & 80 & 90 & 99 & 101 & 133 & 171 \\
Média & 51 & 61 & 71 & 76 & 88 & 94 & 99 & 131 & 149 \\
Sacarose 1 & 46 & 61 & 74 & 73 & 89 & 98 & 100 & 117 & 151 \\
Sacarose 2 & 53 & 57 & 67 & 79 & 88 & 87 & 100 & 124 & 162 \\
Sacarose 3 & 56 & 59 & 79 & 87 & 90 & 95 & 91 & 114 & 178 \\
Sacarose 4 & 50 & 55 & 70 & 84 & 82 & 95 & 108 & 143 & 153 \\
Média & 51 & 58 & 72 & 81 & 87 & 93 & 100 & 124 & 161 \\
Amido de Milho 1 & 47 & 62 & 81 & 80 & 82 & 91 & 80 & 120 & 150 \\
Amido de Milho 2 & 52 & 65 & 73 & 84 & 93 & 94 & 108 & 126 & 138 \\
Amido de Milho 3 & 53 & 59 & 69 & 77 & 86 & 87 & 89 & 118 & 148 \\
Amido de Milho 4 & 50 & 56 & 74 & 82 & 86 & 83 & 97 & 123 & 175 \\
Média & 50 & 60 & 74 & 81 & 87 & 88 & 93 & 122 & 152 \\
Amido de Mandioca 1 & 51 & 63 & 69 & 85 & 86 & 96 & 99 & 131 & 154 \\
Amido de Mandioca 2 & 52 & 58 & 75 & 73 & 91 & 94 & 93 & 137 & 165 \\
Amido de Mandioca 3 & 56 & 61 & 63 & 78 & 89 & 92 & 92 & 122 & 147 \\
Amido de Mandioca 4 & 50 & 60 & 74 & 79 & 73 & 93 & 103 & 125 & 143 \\
Média & 52 & 60 & 70 & 78 & 85 & 94 & 97 & 128 & 152 \\
Lactose 1 & 50 & 62 & 82 & 91 & 91 & 93 & 96 & 134 & 159 \\
Lactose 2 & 50 & 64 & 78 & 90 & 92 & 98 & 101 & 131 & 174 \\
Lactose 3 & 46 & 58 & 73 & 77 & 93 & 95 & 108 & 135 & 146 \\
Lactose 4 & 44 & 64 & 72 & 83 & 93 & 88 & 108 & 131 & 178 \\
Média & 47 & 62 & 76 & 85 & 92 & 93 & 103 & 133 & 164 \\
\hline & & & & & & & & &
\end{tabular}


APÊNDICE 11 - Média de duas aves por parcela da relação do peso do intestino delgado pelo comprimento do mesmo de 1 a 7,21 e 42 dias de idade.

\begin{tabular}{|c|c|c|c|c|c|c|c|c|c|}
\hline \multirow{2}{*}{ Tratamentos } & \multicolumn{9}{|c|}{ Idade (dias) } \\
\hline & 1 & 2 & 3 & 4 & 5 & 6 & 7 & 21 & 42 \\
\hline Testemunha 1 & 0,03 & 0,03 & 0,04 & 0,05 & 0,07 & 0,08 & 0,08 & 0,18 & 0,34 \\
\hline Testemunha 2 & 0,03 & 0,03 & 0,06 & 0,07 & 0,07 & 0,06 & 0,07 & 0,18 & 0,28 \\
\hline Testemunha 3 & 0,04 & 0,05 & 0,05 & 0,06 & 0,10 & 0,09 & 0,09 & 0,21 & 0,28 \\
\hline Testemunha 4 & 0,03 & 0,04 & 0,06 & 0,06 & 0,08 & 0,08 & 0,09 & 0,19 & 0,33 \\
\hline Média & 0,03 & 0,04 & 0,05 & 0,06 & 0,08 & 0,08 & 0,08 & 0,19 & 0,31 \\
\hline Glicose 1 & 0,04 & 0,05 & 0,05 & 0,05 & 0,06 & 0,09 & 0,08 & 0,20 & 0,38 \\
\hline Glicose 2 & 0,03 & 0,03 & 0,05 & 0,06 & 0,07 & 0,09 & 0,10 & 0,19 & 0,34 \\
\hline Glicose 3 & 0,03 & 0,04 & 0,05 & 0,06 & 0,07 & 0,09 & 0,10 & 0,17 & 0,33 \\
\hline Glicose 4 & 0,04 & 0,04 & 0,06 & 0,06 & 0,08 & 0,08 & 0,08 & 0,18 & 0,32 \\
\hline Méd & 0,03 & 0,04 & 0,05 & 0,06 & 0,07 & 0,09 & 0,09 & 0,18 & 0,34 \\
\hline Sacarose 1 & 0,04 & 0,03 & 0,06 & 0,05 & 0,09 & 0,09 & 0,09 & 0,21 & 0,34 \\
\hline Sacarose 2 & 0,04 & 0,05 & 0,06 & 0,07 & 0,07 & 0,09 & 0,08 & 0,17 & 0,33 \\
\hline Sacarose 3 & 0,05 & 0,04 & 0,05 & 0,07 & 0,08 & 0,07 & 0,09 & 0,17 & 0,26 \\
\hline Saca & 0,03 & 0,05 & 0,06 & 0,06 & 0,08 & 0,12 & 0,09 & 0,17 & 0,33 \\
\hline Méc & 0,04 & 0,04 & 0,06 & 0,06 & 0,08 & 0,09 & 0,09 & 0,18 & 0,32 \\
\hline Amido de Milho 1 & 0,03 & 0,05 & 0,05 & 0,07 & 0,07 & 0,08 & 0,08 & 0,18 & 0,31 \\
\hline Amido de Milho 2 & 0,04 & 0,05 & 0,06 & 0,07 & 0,08 & 0,08 & 0,10 & 0,19 & 0,32 \\
\hline Amido & 0,03 & 0,03 & 0,04 & 0,06 & 0,07 & 0,09 & 0,08 & 0,20 & 0,35 \\
\hline Amido & 0,02 & 0,04 & 0,05 & 0,08 & 0,08 & 0,07 & 0,09 & 0,14 & 0,26 \\
\hline Méc & 0,03 & 0,04 & 0,05 & 0,07 & 0,08 & 0,08 & 0,09 & 0,18 & 0,31 \\
\hline A. Mandioca 1 & 0,04 & 0,04 & 0,05 & 0,06 & 0,08 & - & 0,08 & 0,20 & 0,33 \\
\hline A. Mandioca 2 & 0,03 & 0,05 & 0,05 & 0,06 & 0,07 & 0,11 & 0,09 & 0,18 & 0,27 \\
\hline A. Mandioca 3 & 0,04 & 0,05 & 0,05 & 0,06 & 0,07 & 0,08 & 0,09 & 0,23 & 0,32 \\
\hline A. Mandioca 4 & 0,03 & 0,04 & 0,06 & 0,05 & 0,05 & 0,10 & 0,09 & 0,18 & 0,31 \\
\hline Méd & 0,03 & 0,05 & 0,05 & 0,06 & 0,07 & 0,10 & 0,09 & 0,20 & 0,31 \\
\hline Lactose 1 & 0,03 & 0,04 & 0,06 & 0,06 & 0,08 & 0,09 & 0,09 & 0,19 & 0,39 \\
\hline Lactose 2 & 0,03 & 0,04 & 0,06 & 0,06 & 0,07 & 0,08 & 0,10 & 0,17 & 0,28 \\
\hline & 0,03 & 0,04 & 0,05 & 0,05 & 0,07 & 0,09 & 0,09 & 0,20 & 0,37 \\
\hline Lact & 0,02 & 0,04 & 0,07 & 0,06 & 0,06 & 0,09 & 0,09 & 0,16 & 0,35 \\
\hline Média & 0,03 & 0,04 & 0,06 & 0,06 & 0,07 & 0,09 & 0,09 & 0,18 & 0,35 \\
\hline
\end{tabular}


APÊNDICE 12 - Média de duas aves por parcela do peso relativo do pâncreas (\% do peso vivo) de 1 a 7,21 e 42 dias de idade.

\begin{tabular}{|c|c|c|c|c|c|c|c|c|c|}
\hline \multirow{2}{*}{ Tratamentos } & \multicolumn{9}{|c|}{ Idade (dias) } \\
\hline & 1 & 2 & 3 & 4 & 5 & 6 & 7 & 21 & 42 \\
\hline Testemunha 1 & 0,29 & 0,38 & 0,48 & 0,46 & 0,41 & 0,54 & 0,39 & 0,43 & 0,21 \\
\hline Testemunha 2 & 0,38 & 0,44 & 0,49 & 0,49 & 0,52 & 0,41 & 0,49 & 0,40 & 0,20 \\
\hline Testemunha 3 & 0,28 & 0,31 & 0,45 & 0,48 & 0,44 & 0,51 & 0,61 & 0,28 & 0,19 \\
\hline Testemunha 4 & 0,31 & 0,41 & 0,47 & 0,43 & 0,47 & 0,51 & 0,43 & 0,30 & 0,18 \\
\hline Média & 0,32 & 0,38 & 0,47 & 0,46 & 0,46 & 0,49 & 0,48 & 0,35 & 0,19 \\
\hline Glicose 1 & 0,22 & 0,48 & 0,41 & 0,49 & 0,49 & 0,51 & 0,44 & 0,35 & 0,20 \\
\hline Glicose 2 & 0,30 & 0,36 & 0,43 & 0,65 & 0,50 & 0,45 & 0,47 & 0,24 & 0,20 \\
\hline Glicose 3 & 0,33 & 0,39 & 0,39 & 0,40 & 0,42 & 0,48 & 0,51 & 0,31 & 0,19 \\
\hline Glicose 4 & 0,24 & 0,31 & 0,50 & 0,66 & 0,42 & 0,60 & 0,44 & 0,24 & 0,22 \\
\hline Média & 0,27 & 0,39 & 0,43 & 0,55 & 0,46 & 0,51 & 0,47 & 0,29 & 0,20 \\
\hline Sacarose 1 & 0,26 & 0,47 & 0,50 & 0,43 & 0,63 & 0,48 & 0,51 & 0,33 & 0,20 \\
\hline Sacar & 0,24 & 0,38 & 0,49 & 0,51 & 0,47 & 0,65 & 0,46 & 0,30 & 0,18 \\
\hline Sacarose 3 & 0,22 & 0,43 & 0,53 & 0,71 & 0,51 & 0,56 & 0,50 & 0,32 & 0,21 \\
\hline Saca & 0,19 & 0,36 & 0,43 & 0,34 & 0,52 & 0,40 & 0,51 & 0,30 & 0,23 \\
\hline Média & 0,23 & 0,41 & 0,49 & 0,50 & 0,53 & 0,52 & 0,50 & 0,31 & 0,21 \\
\hline Amido de Milho 1 & 0,18 & 0,42 & 0,54 & 0,39 & 0,50 & 0,67 & 0,56 & 0,22 & 0,23 \\
\hline Amido de Milho 2 & 0,32 & 0,42 & 0,46 & 0,54 & 0,47 & 0,59 & 0,49 & 0,37 & 0,25 \\
\hline Amido de Milho 3 & 0,31 & 0,41 & 0,55 & 0,61 & 0,46 & 0,47 & 0,42 & 0,29 & 0,20 \\
\hline Amido & 0,25 & 0,23 & 0,55 & 0,48 & 0,51 & 0,62 & 0,52 & 0,29 & 0,21 \\
\hline Média & 0,26 & 0,37 & 0,52 & 0,50 & 0,48 & 0,59 & 0,49 & 0,29 & 0,22 \\
\hline Amido de Mandioca 1 & 0,30 & 0,31 & 0,46 & 0,49 & 0,50 & 0,48 & 0,51 & 0,31 & 0,18 \\
\hline Amido de Mandioca 2 & 0,33 & 0,35 & 0,63 & 0,54 & 0,52 & 0,45 & 0,50 & 0,31 & 0,19 \\
\hline Amido de Mandioca 3 & 0,27 & 0,44 & 0,46 & 0,62 & 0,47 & 0,44 & 0,52 & 0,30 & 0,19 \\
\hline Amido de Mandioca 4 & 0,24 & 0,32 & 0,40 & 0,53 & 0,42 & 0,49 & 0,58 & 0,32 & 0,18 \\
\hline Média & 0,28 & 0,36 & 0,49 & 0,54 & 0,48 & 0,46 & 0,53 & 0,31 & 0,19 \\
\hline Lactose 1 & 0,29 & 0,40 & 0,54 & 0,53 & 0,51 & 0,54 & 0,46 & 0,30 & 0,23 \\
\hline Lactose 2 & 0,29 & 0,53 & 0,46 & 0,51 & 0,51 & 0,56 & 0,46 & 0,27 & 0,21 \\
\hline Lactose 3 & 0,20 & 0,43 & 0,44 & 0,47 & 0,47 & 0,63 & 0,50 & 0,27 & 0,21 \\
\hline Lactose 4 & 0,17 & 0,41 & 0,43 & 0,50 & 0,54 & 0,39 & 0,47 & 0,26 & 0,20 \\
\hline Média & 0,24 & 0,44 & 0,47 & 0,50 & 0,51 & 0,53 & 0,47 & 0,27 & 0,21 \\
\hline
\end{tabular}


APÊNDICE 13 - Média de duas aves por parcela do peso relativo do fígado (\% do peso vivo) de 1 a 7,21 e 42 dias de idade.

\begin{tabular}{|c|c|c|c|c|c|c|c|c|c|}
\hline \multirow{2}{*}{ Tratamentos } & \multicolumn{9}{|c|}{ Idade (dias) } \\
\hline & 1 & 2 & 3 & 4 & 5 & 6 & 7 & 21 & 42 \\
\hline Testemunha 1 & 3,43 & 5,42 & 5,19 & 5,60 & 5,07 & 4,76 & 4,50 & 2,61 & 2,23 \\
\hline Testemunha 2 & 3,85 & 5,49 & 5,54 & 6,45 & 5,20 & 4,80 & 4,44 & 2,46 & 1,91 \\
\hline Testemunha 3 & 3,88 & 4,59 & 5,34 & 5,48 & 4,72 & 4,66 & 4,61 & 2,08 & 1,79 \\
\hline Testemunha 4 & 4,34 & 5,15 & 5,87 & 4,93 & 4,79 & 4,38 & 4,72 & 2,54 & 2,04 \\
\hline Média & 3,87 & 5,16 & 5,48 & 5,62 & 4,94 & 4,65 & 4,57 & 2,42 & 1,99 \\
\hline Glicose 1 & 3,75 & 6,18 & 6,00 & 5,12 & 4,68 & 5,52 & 5,47 & 3,77 & 1,97 \\
\hline Glicose 2 & 3,50 & 5,33 & 6,08 & 5,42 & 5,57 & 6,09 & 4,73 & 2,70 & 1,64 \\
\hline Glicose 3 & 3,88 & 5,26 & 6,11 & 5,60 & 5,64 & 4,72 & 5,57 & 2,44 & 1,70 \\
\hline Glicose 4 & 3,81 & 5,78 & 6,26 & 5,85 & 5,22 & 5,82 & 4,91 & 2,27 & 1,97 \\
\hline Média & 3,74 & 5,64 & 6,11 & 5,50 & 5,28 & 5,54 & 5,17 & 2,80 & 1,82 \\
\hline Sacarose 1 & 3,57 & 5,39 & 5,84 & 5,47 & 4,81 & 4,09 & 4,73 & 2,98 & 2,08 \\
\hline Sacar & 4,10 & 5,63 & 5,54 & 5,75 & 5,23 & 4,70 & 5,34 & 2,33 & 2,18 \\
\hline Sacarose 3 & 3,61 & 4,87 & 5,34 & 5,12 & 5,28 & 6,24 & 4,98 & 2,22 & 2,42 \\
\hline Sacar & 3,54 & 4,82 & 5,53 & 4,92 & 4,71 & 4,42 & 5,63 & 2,49 & 1,83 \\
\hline Média & 3,70 & 5,18 & 5,56 & 5,32 & 5,01 & 4,86 & 5,17 & 2,50 & 2,13 \\
\hline Amido de Milho 1 & 3,01 & 4,51 & 5,50 & 4,87 & 6,20 & 5,77 & 4,56 & 2,90 & 2,18 \\
\hline Amido de Milho 2 & 3,91 & 5,05 & 5,75 & 4,65 & 4,75 & 5,35 & 4,85 & 2,42 & 1,88 \\
\hline Amido de Milho 3 & 3,51 & 5,25 & 5,07 & 5,32 & 4,61 & 4,51 & 4,75 & 2,89 & 1,92 \\
\hline Amido & 3,51 & 3,99 & 5,36 & 4,49 & 4,62 & 4,80 & 4,24 & 2,22 & 2,45 \\
\hline Média & 3,49 & 4,70 & 5,42 & 4,83 & 5,04 & 5,11 & 4,60 & 2,61 & 2,11 \\
\hline Amido de Mandioca 1 & 3,50 & 5,25 & 5,25 & 4,97 & 5,03 & 6,03 & 4,66 & 2,27 & 1,98 \\
\hline Amido de Mandioca 2 & 3,80 & 4,83 & 5,46 & 6,04 & 4,70 & 4,58 & 5,21 & 2,40 & 1,77 \\
\hline Amido de Mandioca 3 & 3,69 & 4,72 & 5,87 & 6,24 & 4,91 & 4,30 & 4,52 & 2,10 & 2,16 \\
\hline Amido de Mandioca 4 & 3,30 & 4,78 & 4,78 & 5,72 & 4,25 & 4,81 & 4,58 & 2,29 & 2,05 \\
\hline Módia & 3,57 & 4,90 & 5,34 & 5,74 & 4,72 & 4,93 & 4,74 & 2,27 & 1,99 \\
\hline Lactose 1 & 3,25 & 5,06 & 5,25 & 4,15 & 5,17 & 4,95 & 5,11 & 3,04 & 1,90 \\
\hline Lactose 2 & 3,31 & 4,65 & 5,45 & 4,98 & 4,57 & 4,39 & 4,86 & 2,01 & 1,88 \\
\hline Lactose 3 & 3,17 & 4,73 & 5,21 & 5,74 & 5,58 & 4,56 & 4,85 & 2,16 & 2,12 \\
\hline Lactose 4 & 3,08 & 4,70 & 4,81 & 4,85 & 4,93 & 5,73 & 4,69 & 2,39 & 2,03 \\
\hline Média & 3,20 & 4,78 & 5,18 & 4,93 & 5,06 & 4,91 & 4,88 & 2,40 & 1,98 \\
\hline
\end{tabular}

